\title{
Genome sequencing and analysis of the first spontaneous Nanosilver resistant bacterium Proteus mirabilis strain SCDR1
}

\author{
Amr T. M. Saeb ${ }^{*^{*}}$ (D), Khalid A. Al-Rubeaan ${ }^{1}$, Mohamed Abouelhoda ${ }^{2,3}$, Manojkumar Selvaraju 3,4 \\ and Hamsa T. Tayeb 2,3
}

\begin{abstract}
Background: P. mirabilis is a common uropathogenic bacterium that can cause major complications in patients with long-standing indwelling catheters or patients with urinary tract anomalies. In addition, $P$. mirabilis is a common cause of chronic osteomyelitis in Diabetic foot ulcer (DFU) patients. We isolated P. mirabilis SCDR1 from a Diabetic ulcer patient. We examined P. mirabilis SCDR1 levels of resistance against Nanosilver colloids, the commercial Nanosilver and silver containing bandages and commonly used antibiotics. We utilized next generation sequencing techniques (NGS), bioinformatics, phylogenetic analysis and pathogenomics in the characterization of the infectious pathogen.
\end{abstract}

Results: P. mirabilis SCDR1 was the first Nanosilver resistant isolate collected from a diabetic patient polyclonal infection. P. mirabilis SCDR1 showed high levels of resistance against Nanosilver colloids, Nanosilver chitosan composite and the commercially available Nanosilver and silver bandages. The $P$. mirabilis -SCDR1 genome size is 3,815,621 bp. with $\mathrm{G}+\mathrm{C}$ content of $38.44 \%$. P. mirabilis-SCDR1 genome contains a total of 3533 genes, 3414 coding DNA sequence genes, 11, 10, 18 rRNAs (5S, 16S, and 23S), and 76 tRNAs. Our isolate contains all the required pathogenicity and virulence factors to establish a successful infection. P. mirabilis SCDR1 isolate is a potential virulent pathogen that despite its original isolation site, the wound, can establish kidney infection and its associated complications. P. mirabilis SCDR1 contains several mechanisms for antibiotics and metals resistance, including, biofilm formation, swarming mobility, efflux systems, and enzymatic detoxification.

Conclusion: P. mirabilis SCDR1 is the first reported spontaneous Nanosilver resistant bacterial strain. P. mirabilis SCDR1 possesses several mechanisms that may lead to the observed Nanosilver resistance.

Keywords: Proteus Mirabilis, Multi-drug resistance, Silver nanoparticles, Genome analysis, Pathogenomics, Biofilm formation, Swarming mobility, Resistome, Glutathione S-transferase, Copper/silver efflux system

\section{Background}

The production and utilization of nanosilver is one of the primary and still growing applications in the field of nanotechnology. Nanosilver is used as the essential antimicrobial ingredient in both clinical and environmental technologies. Nanosilver is utilized in the formulation of dental resin amalgams, medical device coatings, water filter antimicrobial coating, antimicrobial agents in air sanitizers, textiles, pillows,

\footnotetext{
*Correspondence: saeb.1@osu.edu

${ }^{1}$ Genetics and Biotechnology Department, Strategic Center for Diabetes Research, College of medicine, King Saud University, Riyadh, Kingdom of Saudi Arabia

Full list of author information is available at the end of the article
}

respirators, socks, wet wipes, detergents, soaps, shampoos, toothpastes, washing machines, bone cement, wound dressings, hospital beds and furniture to control infection and support anti-biofilm activity [1-8]. Nanosilver is known to exert inhibitory and bactericidal effects against many Gram-positive, Gram-negative and fungal pathogens [9]. Latest studies suggest that the use of nanosilver-containing wound dressings prevents or reduces microbial growth in wounds, and may improve the healing process [10]. Moreover, antibacterial nanosilver-containing wound dressing gels may be important for patients that are at risk of non-healing of diabetic foot wounds and traumatic/surgical wounds [11]. 
Increased usage of nanosilver in both medical and environmental products has generated concerns about the development of bacterial resistance against the antimicrobial ingredient. Bacterial resistance against metallic silver has been documented with several bacterial strains such as E. coli Enterobacter cloacae, Klebsiella pneumoniae and Salmonella typhimurium [12, 13]. However, information about bacterial resistance against Nanosilver is scarce. Only Gunawan et al., (2013) reported the occurrence of induced adaptation, of non-targeted environmental Bacillus species, to antimicrobial Nanosilver [14]. In this study, we report on a spontaneous nanosilver-resistant Proteus mirabilis isolate ("SCDR1"). Proteus mirabilis is a motile gram-negative bacterium that is characterized by its swarming behavior $[15,16]$. P. mirabilis is a common uropathogen that can cause major complications. In addition, $P$. mirabilis can cause respiratory and wound infections, bacteremia, and other infections [16-21]. In fact, $P$. mirabilis is a common cause of chronic osteomyelitis in Diabetic foot ulcer (DFU) patients along with Bacteroides fragilis, E coli, and Klebsiella pneumoniae [22]. Generally, P. mirabilis is responsible for $90 \%$ of genus Proteus infections, and can be considered as a communityacquired infection [23]. As a pathogen $P$. mirabilis acquires many virulence determinants that enable it to establish successful infections [24-26]. A lot of information concerning antibiotic resistance is available for $P$. mirabilis [27-35]. $P$. mirabilis is intrinsically resistant to tetracyclines and polymyxins. Moreover, multidrug-resistant (MDR) $P$. mirabilis strain resistance to $\beta$-lactams, aminoglycosides, fluoroquinolones, phenicols, streptothricin, tetracycline, and trimethoprim-sulfamethoxazole has been reported [36]. However, limited information about heavy metals, including silver, is available. In this study, we present the first report and genome sequence of the nanosilver resistant bacterium $P$. mirabilis strain SCDR1, isolated from diabetic foot ulcer (DFU) patient.

\section{Methods}

\section{Bacterial isolate}

Proteus mirabilis strain SCDR1 was isolated from a diabetic ulcer patient in the diabetic foot unit at the University Diabetes Center, King Saud University. P. mirabilis SCDR1 was the first nanosilver resistant isolate to be collected from a diabetic patient's polyclonal infection. A Proper wound swab was obtained from the patient and was sent for further microbiological study and culture. Wounds needing debridement were debrided before swabbing the surface of the wound. The specimen was inoculated onto blood agar (BA; Oxoid, Basingstoke, UK) and MacConkey agar (Oxoid) and incubated at $37{ }^{\circ} \mathrm{C}$ for $24-48 \mathrm{~h}$. The Vitek 2 system and its advanced expert system were used for microbial identification, antibiotic sensitivity testing, and the interpretation of results. ID GN cards were used to identify the bacterial isolate, and AST-N204 was used for the antimicrobial susceptibility testing of gram-negative rods. Manual disk diffusion and MIC method for AgNPs and antibiotic sensitivity testing were performed when required. Results were categorized according to EUCAST 2.0 VITEK 2 MIC breakpoints.

\section{Preparation of colloidal and composite Nanosilver and commercial products for antimicrobial activity testing} Colloidal silver nanoparticles were prepared and characterized, and their concentration was determined as described by Saeb et al., 2014 [9]. Nanosilver chitosan composite preparations were made by chemical reduction method, as described by Latif et al., 2015 [37]. Moreover, the following commercially silver and nanosilver containing wound dressing bandages were used for antimicrobial activity testing: Silvercel non-adherent antimicrobial alginate Dressing (Acelity L.P. Inc., San Antonio, Texas, USA), Sorbsan Silver dressing made of Calcium alginate with silver (Aspen Medical Europe Ltd., Leicestershire, UK), ColActive ${ }^{\odot}$ Plus Ag (Covalon Technologies Ltd., Mississauga, Ontario, Canada), exsalt ${ }^{\circ} \mathrm{SD} 7$ wound dressing (Exciton Technologies, Edmonton, Alberta, Canada), Puracol Plus AG+ Collagen Dressings with Silver (Medline, Mundelein, Illinois, USA) and ACTISORB ${ }^{\text {ma }}$ silver antimicrobial wound dressing 220 (Acelity L.P. Inc., San Antonio, Texas, USA).

\section{Antimicrobial susceptibility test}

Antimicrobial activities were performed against the following strains: Pseudomonas aeruginosa ATCC 27853, Staphylococcus aureus ATCC 29213, Proteus mirabilis ATCC 29906, Klebsiella pneumoniae ATCC 700603, E. coli ATCC 25922 and Enterobacter cloacae ATCC 29212.

\section{Disk diffusion antimicrobial susceptibility testing}

Disk diffusion antimicrobial susceptibility testing was performed as described by Matuschek et al. [38]. Briefly, Mueller-Hinton $(\mathrm{MH})$ agar plates were inoculated with agar with an inoculum corresponding to a McFarland 0.5 turbidity with a sterile cotton swab to prepare bacterial lawns of the abovementioned bacterial test strains. Sterile discs were loaded with different concentrations (50$200 \mathrm{ppm}$ ) of colloidal silver nanoparticles solutions and the Nanosilver chitosan composite (composite concentration ranged from $0.1 \%$ and $0.01 \mathrm{M}$ to $3.2 \%$ and $0.16 \mathrm{M}$ from chitosan and Silver nitrate respectively) and then placed on Mueller-Hinton $(\mathrm{MH})$ agar plates with bacterial lawns. Within $15 \mathrm{~min}$ of application of antimicrobial disks, the plates were inverted and incubated at $37^{\circ} \mathrm{C}$ for $16 \mathrm{~h}$. All experiments were done in aseptic conditions in a laminar air flow cabinet. After incubation, inhibition zones were read at the point where no apparent growth was detected. The inhibition zone diameters were measured to the nearest millimeter. Similarly, $5 \mathrm{~mm}$ desks from the commercially available bandages were prepared in aseptic conditions and tested for antimicrobial activity, as previously described. 


\section{Minimum bactericidal (MBC) and minimal inhibitory concertation (MIC) test}

$\mathrm{MBC}$ and MIC testing were performed as described by Holla et al., [39]. Briefly, a dilution with $1 \times 10^{5} \mathrm{CFU} / \mathrm{ml}$ (equivalent to 0.5 McFarland) was used as an inoculum for MIC testing. Different volumes that contained a range of silver Nanoparticles (50-700 ppm) were delivered to $7.5 \mathrm{ml}$ of MullerHinton $(\mathrm{MH})$ broth, each inoculated with $0.2 \mathrm{ml}$ of the bacterial suspensions. Within $15 \mathrm{~min}$ of application of silver nanoparticles, the tubes were incubated at $37^{\circ} \mathrm{C}$ for $16 \mathrm{~h}$ in a shaker incubator at $200 \mathrm{rpm}$. We included a positive control (tubes containing inoculum and nutrient media without silver nanoparticles) and a negative control (tubes containing silver nanoparticles and nutrient media without inoculum).

\section{Biofilm formation}

In order to test the ability of $P$. mirabilis SCDR1 isolate to form biofilm, a culture was prepared by inoculation on Columbia agar, supplemented with $5 \%$ blood and incubated at $37 \mathrm{C}^{\circ}$ for $24 \mathrm{~h}$. The culture was then used to prepare 0.5 McFarland standard bacterial suspension. Wells of sterile 96- well flat- bottomed plastic microplates were filled with $250 \mu \mathrm{L}$ of the Brain-heart infusion broth. Negative control wells contained the broth only. Twenty $\mu \mathrm{L}$ of bacterial suspension were then added to each well. The plate was incubated at $37 \mathrm{C}^{\circ}$ for $24 \mathrm{~h}$. Following the incubation, the content of each well was aspirated and washed three times with $300 \mu \mathrm{L}$ of sterile distilled water. The remaining attached bacteria were fixed with $200 \mu \mathrm{L}$ of methanol per well, and after 15 min the plates were emptied and left to dry air. After this, the plates were stained for $5 \mathrm{~min}$ with $160 \mu \mathrm{L}$ per well of crystal violet used for gram stain. Excess stain was rinsed off by placing the microplates under running tap water. After the plates were air dried, the dye which was bound to the adherent cells was re-solubilized with $160 \mu \mathrm{L}$ of $33 \%(v / v)$ glacial acetic acid per well. The optical density (OD) was measured at $570 \mathrm{~nm}$ [40].

\section{Molecular genomics analysis \\ DNA purification, sequencing, bioinformatics and phylogenetic analysis}

DNA isolation, purification, genome sequencing, bioinformatics and phylogenetic analysis were performed as described by Saeb et al., 2017 [41]. In addition, we used Mauve [42] and CoCoNUT [43] to generate the whole genome pairwise and multiple alignments of the draft $P$. mirabilis strain SCDR1 genome against selected reference genomes. Furthermore, we performed whole genome phylogeny based proteomic comparison among P. mirabilis SCDR1 isolate and other related Proteus mirabilis strains using Proteome Comparison service which is a protein sequence-based comparison using bi-directional BLASTP available at (https:// www.patricbrc.org/app/SeqComparison) [44].

\section{Gene annotation and Pathogenomics analysis}

$P$. mirabilis SCDR1 genome contigs were annotated using the Prokaryotic Genomes Automatic Annotation Pipeline (PGAAP) available at NCBI (http:// www.ncbi.nlm.nih.gov/). In addition, contigs were further annotated using the bacterial bioinformatics database and analysis resource (PATRIC) gene annotation service (https://www.patricbrc.org/app/Annotation) [44]. The PathogenFinder $\mathbf{1 . 1}$ pathogenicity prediction program available at (https://cge.cbs.dtu.dk/ services/PathogenFinder/) was used to examine the nature of $P$. mirabilis SCDR1 as a human pathogen [45]. Virulence gene sequences and functions, corresponding to different major bacterial virulence factors of Proteus mirabilis were collected from GenBank and validated using virulence factors of the pathogenic bacteria database available at (http://www.mgc.ac.cn/ $\mathrm{VFs} /$ ) [46], the Victors virulence factors search program available at (http://www.phidias.us/victors/) and the PATRIC_VF tool available at https:// www.patricbrc.org/ $=[44]$.

\section{Resistome analysis}

P. mirabilis SCDR1 genome contigs were investigated manually for the presence of antibiotic resistance loci using the PGAAP and PATRIC gene annotation services. Antibiotic resistance loci were further investigated using specialized search tools and services, namely Antibiotic Resistance Gene Search available at (https://www.patricbrc.org/=) [44], Genome Feature Finder (antibiotic resistance) available at (https://www.patricbrc.org/=) [44], ARDB (Antibiotic Resistance Genes Database) available at (https:// ardb.cbcb.umd.edu/) [47],

CARD (The Comprehensive Antibiotic Resistance Database) available at (https://card.mcmaster.ca/) [48, 49], Specialty Gene Search available at (https://www.patricbrc.org/=) and ResFinder 2.1 available at (https://cge.cbs.dtu.dk//services/ResFinder/) [50].

The heavy metal resistance gene search for $P$. mirabilis SCDR1 contigs were investigated using PGAAP and PATRIC gene annotation services, PATRIC Feature Finder searches tool and BacMet (antibacterial biocide and metal resistance genes database) available at (http:// bacmet.biomedicine.gu.se/) [44, 51].

\section{Results}

Initial identification and antimicrobial susceptibility test The Vitek 2 system showed that our isolate belongs to the Proteus mirabilis species. Antibiotic sensitivity testing using Vitek 2 AST-N204 card showed that our isolate $P$. mirabilis SCDR1 is resistant to ampicillin, nitrofurantoin, and Trimethoprim/ Sulfamethoxazole. In addition, $P$. mirabilis SCDR1 was resistant to ethidium bromide, 
tetracycline, tigecycline, colistin, polymyxin B, rifamycin, doxycycline, vancomycin, fusidic acid, bacitracin, metronidazole, clarithromycin, erythromycin, oxacillin, clindamycin, trimethoprim, novobiocin, and minocycline. $P$. mirabilis SCDR1 was intermediate resistant against nalidixic acid, Imipenem, and Cefuroxime. Conversely, it was sensitive to chloramphenicol, amoxicillin/ clavulanic Acid, piperacillin/tazobactam, cefotaxime, ceftazidime, cefepime, cefaclor, cephalothin, ertapenem, meropenem, amikacin, gentamicin, ciprofloxacin, norfloxacin, tobramycin, streptomycin, and fosfomycin.

$P$. mirabilis SCDR1 isolate showed high resistance against colloidal and composite Nanosilver and metallic silver compared with other tested Gram positive and negative bacterial species. For instance, Table 1, shows the resistance of $P$. mirabilis SCDR1 against colloidal Nanosilver assessed by the disk diffusion method, in comparison with $S$. aureus ATCC 29213, P. aeruginosa ATCC 27853, E. coli ATCC 25922 and E. cloacae ATCC 29212. Generally, P. mirabilis $S C D R 1$ showed high resistance $(0.0 \mathrm{~cm})$, while $K$. pneumoniae showed the highest sensitivity $(1.5-1.9 \mathrm{~cm})$ against all tested silver nanoparticle concentrations (50-200 ppm). $S$. aureus also showed high sensitivity $(1.4-1.6 \mathrm{~cm})$ against all tested silver nanoparticle concentrations. None of the tested bacterial isolates except for P. mirabilis SCDR1 showed any resistance against silver-nanoparticles, even against the lowest concentration (50 ppm). Furthermore, Table 2 shows the resistance of $P$. mirabilis SCDR1 against colloidal Nanosilver assessed by a minimal inhibitory concentration method, compared with other tested Gram positive and negative bacterial species. Once more, $P$. mirabilis SCDR1 showed high resistance against the gradually increased concentrations of colloidal nanosilver. We observed P. mirabilis SCDR1 bacterial growth to colloidal Nanosilver concentration up to $500 \mathrm{ppm}$. On the other hand, K. pneumoniae showed the highest sensitivity against silver nanoparticles, with no observed growth at only $100 \mathrm{ppm}$ colloidal nanosilver concentration. In addition, both $E$. coli and $P$. aeruginosa showed high sensitivity against silver nanoparticles, with no observed growth at $150 \mathrm{ppm}$ colloidal Nanosilver concentration. Conversely, S. aureus tolerated only $200 \mathrm{ppm}$ colloidal Nanosilver concentration. Similarly, Table 3 shows the resistance of $P$. mirabilis SCDR1 against silver and Nanosilver composite assessed by disk diffusion method. Nanosilver chitosan composites, with a concentration ranging from between $0.1 \%$ and $0.01 \mathrm{M}$ to $3.2 \%$ and $0.16 \mathrm{M}$ from chitosan and Silver nitrate respectively, had a comparable killing effect on both Gram positive and negative bacterial, namely $S$. aureus and $P$. aeruginosa. Meanwhile, none of the tested Nanosilver chitosan composites had any killing effect on P. mirabilis SCDR1. Similarly, all the tested commercially available silver and Nanosilver containing wound dressing bandages showed the enhanced killing effect on both $S$. aureus and P. aeruginosa. However, all these wound dressing bandages failed to inhibit $P$. mirabilis SCDR1 growth. $P$. mirabilis SCDR1 was able to produce strong biofilm with OD of 0.296 .

\section{General genome features}

Data from our draft genome of $P$. mirabilis SCDR1 was deposited in the NCBI-GenBank and was assigned accession number LUFT00000000. The bacterial bioinformatics database and analysis resource (PATRIC) gene annotation analysis showed the presence 308 unique genes of the biosynthesis of secondary metabolites such as tetracycline, Streptomycin, Novobiocin, and Betalain. It is also noteworthy that Xenobiotics Biodegradation and Metabolism pathways also maintained a high number of dedicated unique gene (245) (Additional files 1 and 2: Tables S1 and S2).

\section{Pathogen identification and phylogenetic analysis}

As previously stated, biochemical identification of the isolate confirmed the identity of our isolate as belonging to the Proteus mirabilis species. Moreover, Primary analysis of Metaphlan showed that Proteus mirabilis is the most dominant species in the sample (Fig. 1). The appearance of other bacterial species in the Metaphlan diagram is explained by the genomic homology similarity of other bacteria to Proteus mirabilis. P. mirabilis SCDR1 genome showed high similarly, $92.07 \%$, to the genome of $P$. mirabilis strain BB2000 followed by $P$. mirabilis strain C05028 (90.99\%) and P. mirabilis strain PR03 (89.73\%) (Table 4). A similar scenario was observed when constructing the phylogenetic relationship between our isolate and other Proteus mirabilis available in the NCBIGenBank. 16Sr DNA-based maximum likelihood phylogenetic tree (Fig. 2) showed that our isolate is located within a large clade that contains the majority of Proteus mirabilis strains and isolates. In addition, $P$. mirabilis SCDR1 was

Table 1 Resistance of P. mirabilis SCDR1 against colloidal Nano-Silver assessed by desk diffusion method

\begin{tabular}{llllllll}
\hline S. No. & Sample ID & $\begin{array}{l}\text { Zone Of Inhibition } \\
(\mathrm{cm}) \text { S. aureus }\end{array}$ & $\begin{array}{l}\text { Zone Of Inhibition } \\
(\mathrm{cm}) \text { E. cloacae }\end{array}$ & $\begin{array}{l}\text { Zone Of Inhibition } \\
(\mathrm{cm}) \text { P. aeruginosa }\end{array}$ & $\begin{array}{l}\text { Zone Of Inhibition } \\
(\mathrm{cm}) \text { E. coli }\end{array}$ & $\begin{array}{l}\text { Zone Of Inhibition } \\
(\mathrm{cm}) \text { K. pneumoniae }\end{array}$ & $\begin{array}{l}\text { Zone Of Inhibition } \\
(\mathrm{cm}) \text { P. mirabilis SCDR1 }\end{array}$ \\
\hline 1 & $200 \mathrm{ppm}$ & $1.6 \mathrm{~cm}$ & $1.5 \mathrm{~cm}$ & $1.4 \mathrm{~cm}$ & $1.1 \mathrm{~cm}$ & $1.9 \mathrm{~cm}$ & $0.0 \mathrm{~cm}$ \\
2 & $150 \mathrm{ppm}$ & $1.5 \mathrm{~cm}$ & $1.2 \mathrm{~cm}$ & $1.3 \mathrm{~cm}$ & $1.0 \mathrm{~cm}$ & $1.7 \mathrm{~cm}$ & $0.0 \mathrm{~cm}$ \\
3 & $100 \mathrm{ppm}$ & $1.5 \mathrm{~cm}$ & $1.2 \mathrm{~cm}$ & $1.3 \mathrm{~cm}$ & $1.0 \mathrm{~cm}$ & $1.6 \mathrm{~cm}$ & $0.0 \mathrm{~cm}$ \\
4 & $50 \mathrm{ppm}$ & $1.4 \mathrm{~cm}$ & $1.1 \mathrm{~cm}$ & $1.1 \mathrm{~cm}$ & $0.9 \mathrm{~cm}$ & $1.5 \mathrm{~cm}$ & $0.0 \mathrm{~cm}$ \\
\hline
\end{tabular}


Table 2 Resistance of P. mirabilis SCDR1 against colloidal Nanosilver assessed by minimal inhibitory concentration method

\begin{tabular}{|c|c|c|c|c|c|c|c|}
\hline \multirow{2}{*}{$\begin{array}{l}\text { AgNPs (concentration } \\
\text { in ppm) }\end{array}$} & \multirow[b]{2}{*}{$\begin{array}{l}\text { S. aureus } \\
\text { ATCC } 29213\end{array}$} & \multirow[b]{2}{*}{$\begin{array}{l}\text { P. aeruginosa } \\
\text { ATCC } 27853\end{array}$} & \multicolumn{5}{|c|}{ Bacterial species/strain } \\
\hline & & & $\begin{array}{l}\text { E. cloacae } \\
\text { ATCC } 29212\end{array}$ & $\begin{array}{l}\text { E. coli } \\
\text { ATCC } 25922\end{array}$ & $\begin{array}{l}\text { K. pneumoniae } \\
\text { ATCC } 700603\end{array}$ & $\begin{array}{l}\text { P. mirabilis } \\
\text { SCDR1 }\end{array}$ & $\begin{array}{l}\text { P. mirabilis } \\
\text { ATCC } 29906\end{array}$ \\
\hline 50 & Growth & Growth & Growth & Growth & Growth & Growth & Growth \\
\hline 100 & Growth & Growth & Growth & Growth & No Growth & Growth & Growth \\
\hline 150 & Growth & No Growth & Growth & No Growth & No Growth & Growth & Growth \\
\hline 200 & Growth & No Growth & Growth & No Growth & No Growth & Growth & Growth \\
\hline 250 & No Growth & No Growth & No Growth & No Growth & No Growth & Growth & Growth \\
\hline 300 & No Growth & No Growth & No Growth & No Growth & No Growth & Growth & Growth \\
\hline 350 & No Growth & No Growth & No Growth & No Growth & No Growth & Growth & Growth \\
\hline 400 & No Growth & No Growth & No Growth & No Growth & No Growth & Growth & Growth \\
\hline 450 & No Growth & No Growth & No Growth & No Growth & No Growth & Growth & Growth \\
\hline 500 & No Growth & No Growth & No Growth & No Growth & No Growth & Growth & No Growth \\
\hline 550 & No Growth & No Growth & No Growth & No Growth & No Growth & No Growth & No Growth \\
\hline 600 & No Growth & No Growth & No Growth & No Growth & No Growth & No Growth & No Growth \\
\hline 650 & No Growth & No Growth & No Growth & No Growth & No Growth & No Growth & No Growth \\
\hline 700 & No Growth & No Growth & No Growth & No Growth & No Growth & No Growth & No Growth \\
\hline
\end{tabular}

S. aureus: $250 \mathrm{ppm} / 7.5$

P. aeruginosa: $150 \mathrm{ppm} / 7.5$

E. cloacae: $250 \mathrm{ppm} / 7.5$

P. mirabilis SCDR1: $550 \mathrm{ppm} / 7.5$

P. mirabilis ATCC: $500 \mathrm{ppm} / 7.5$

shown to be closely related to the reference strain $P$. mirabilis HI4320 compared with P. mirabilis BB2000, which is located in another clade of four Proteus mirabilis taxa. On the contrary, the whole genome Neighbor-joining phylogenetic tree of Proteus mirabilis spices including P. mirabilis SCDR1 isolate (Fig. 3), showed that our isolate was more closely related to $P$. mirabilis BB2000 compared with the reference strain/genome $P$. mirabilis HI4320. However, Fig. 4 showed that $P$. mirabilis SCDR1 exhibited obvious genetic divergence from other Proteus mirabilis species. Similar results were observed when performing pairwise pair-wise whole genome alignment of $P$. mirabilis strain SCDR1 against reference genomes (Fig. 4). This was also confirmed with the clear divergence among $P$. mirabilis SCDR1 Proteus mirabilis species at the proteomic level (Fig. 5).

\section{Bacterial pathogenic and virulence factors}

Pathogenomics analysis using PathogenFinder 1.1 showed that our input organism was predicted as a human pathogen, and the probability of being a human pathogen was 0.857. P. mirabilis SCDR1 comparative proteome analysis showed 35 matched hits from pathogenic families and only one hit from non-pathogenic families (Additional file 3: Table S3). In addition, genome analysis showed that $P$. mirabilis SCDR1 isolate contains numerous virulence factor genes and/or operons that marks it out to be a virulent pathogenic bacterium.
These virulence factors include swarming behavior, mobility (flagellae), adherence, toxin and hemolysin production, Urease, Quorum sensing, iron acquisition systems, proteins that function in immune evasion, cell invasion and biofilm formation, stress tolerance factors, and chemotaxis related factors (Additional file 4: Table S4).

\section{Proteus Mirabilis SCDR1 Resistome Antibiotic resistance}

Antibiotic resistance identification Perfect and Strict analysis using Resistance Gene Identifier (RGI) showed that P. mirabilis SCDR1 isolate contains 34 antibiotic resistance genes that serve in 21 antibiotic resistance functional categories (Additional file 5: Table S5 and Fig. 6). Meanwhile, using the less strict (Loose) antibiotic resistance identification criteria identified 3750 hits in P. mirabilis SCDR1 genome that represent potential AROs (Antibiotic Resistance Ontology) that fall into 59 antibiotic resistance functional categories (Fig. 7) of which 38 are considered to lose antibiotic resistance functional categories. Modified loose antibiotic resistance identification criteria, by removing all hits with objectionable e-values, lead to a number of 366 antibiotic resistance related hits (Additional file 6: Table S6 and Fig. 7). Manual genome annotation based mining resulted in the identification of 64 drug resistance related proteins in $P$. mirabilis SCDR1 genome (Additional file 7: Table S7). 
Table 3 Resistance of P. mirabilis SCDR1 against silver and Nanosilver composite assessed by desk diffusion method

\begin{tabular}{|c|c|c|c|}
\hline \multirow[t]{2}{*}{ Sample ID } & $\begin{array}{l}\text { Zone Of } \\
\text { Inhibition }(\mathrm{cm})\end{array}$ & $\begin{array}{l}\text { Zone Of } \\
\text { Inhibition (cm) }\end{array}$ & $\begin{array}{l}\text { Zone Of } \\
\text { Inhibition (cm) }\end{array}$ \\
\hline & S. aureus & $P$. aeruginosa & P. mirabilis SCDR1 \\
\hline A & $0.9 \mathrm{~cm}$ & $0.8 \mathrm{~cm}$ & No. Inhibition \\
\hline B & $0.9 \mathrm{~cm}$ & $0.9 \mathrm{~cm}$ & No. Inhibition \\
\hline C & $0.8 \mathrm{~cm}$ & $0.9 \mathrm{~cm}$ & No. Inhibition \\
\hline D & $0.8 \mathrm{~cm}$ & $0.9 \mathrm{~cm}$ & No. Inhibition \\
\hline$E$ & $0.9 \mathrm{~cm}$ & $0.9 \mathrm{~cm}$ & No. Inhibition \\
\hline $\mathrm{F}$ & $0.8 \mathrm{~cm}$ & $0.8 \mathrm{~cm}$ & No. Inhibition \\
\hline G & $0.7 \mathrm{~cm}$ & $0.7 \mathrm{~cm}$ & No. Inhibition \\
\hline $\mathrm{H}$ & $0.9 \mathrm{~cm}$ & $0.9 \mathrm{~cm}$ & No. Inhibition \\
\hline | & $0.9 \mathrm{~cm}$ & $1.0 \mathrm{~cm}$ & No. Inhibition \\
\hline J & $0.9 \mathrm{~cm}$ & $1.0 \mathrm{~cm}$ & No. Inhibition \\
\hline K & $0.8 \mathrm{~cm}$ & $0.6 \mathrm{~cm}$ & No. Inhibition \\
\hline L & $0.8 \mathrm{~cm}$ & $0.8 \mathrm{~cm}$ & No. Inhibition \\
\hline M & $0.9 \mathrm{~cm}$ & $0.8 \mathrm{~cm}$ & No. Inhibition \\
\hline N & $0.9 \mathrm{~cm}$ & $0.9 \mathrm{~cm}$ & No. Inhibition \\
\hline O & $1.0 \mathrm{~cm}$ & $0.9 \mathrm{~cm}$ & No. Inhibition \\
\hline$P$ & $0.8 \mathrm{~cm}$ & $0.8 \mathrm{~cm}$ & No. Inhibition \\
\hline Q & $0.9 \mathrm{~cm}$ & $0.7 \mathrm{~cm}$ & No. Inhibition \\
\hline R & $0.9 \mathrm{~cm}$ & $0.8 \mathrm{~cm}$ & No. Inhibition \\
\hline S & $0.8 \mathrm{~cm}$ & $0.9 \mathrm{~cm}$ & No. Inhibition \\
\hline $\mathrm{T}$ & $1.0 \mathrm{~cm}$ & $0.9 \mathrm{~cm}$ & No. Inhibition \\
\hline U & $0.8 \mathrm{~cm}$ & $0.8 \mathrm{~cm}$ & No. Inhibition \\
\hline V & $0.9 \mathrm{~cm}$ & $0.8 \mathrm{~cm}$ & No. Inhibition \\
\hline W & $0.9 \mathrm{~cm}$ & $0.8 \mathrm{~cm}$ & No. Inhibition \\
\hline$x$ & $1.0 \mathrm{~cm}$ & $0.8 \mathrm{~cm}$ & No. Inhibition \\
\hline Y & $0.8 \mathrm{~cm}$ & $0.8 \mathrm{~cm}$ & No. Inhibition \\
\hline Z & $0.7 \mathrm{~cm}$ & $0.7 \mathrm{~cm}$ & No. Inhibition \\
\hline A1 & $0.8 \mathrm{~cm}$ & $0.7 \mathrm{~cm}$ & No. Inhibition \\
\hline B2 & $0.9 \mathrm{~cm}$ & $0.7 \mathrm{~cm}$ & No. Inhibition \\
\hline C3 & $0.9 \mathrm{~cm}$ & $0.8 \mathrm{~cm}$ & No. Inhibition \\
\hline D4 & $0.6 \mathrm{~cm}$ & NA & No. Inhibition \\
\hline Silvercel & $1.3 \mathrm{~cm}$ & $1.4 \mathrm{~cm}$ & No. Inhibition \\
\hline Sorbsan silver & $1.9 \mathrm{~cm}$ & $2.0 \mathrm{~cm}$ & No. Inhibition \\
\hline Colactive $^{\circledast}$ Plus Ag & $1.5 \mathrm{~cm}$ & $2.0 \mathrm{~cm}$ & No. Inhibition \\
\hline Exsaltt ${ }^{T M}$ SD7 & $1.5 \mathrm{~cm}$ & $1.5 \mathrm{~cm}$ & No. Inhibition \\
\hline Puracol ${ }^{\circledR}$ Plus Ag & $1.4 \mathrm{~cm}$ & $2.0 \mathrm{~cm}$ & No. Inhibition \\
\hline Actisorb ${ }^{\circledR}$ Silver 220 & $0.9 \mathrm{~cm}$ & $1.2 \mathrm{~cm}$ & No. Inhibition \\
\hline
\end{tabular}

\section{Proteus Mirabilis comparative genomics based resistome analysis}

We performed a species-wide antibiotic resistome constituent analysis of $P$. mirabilis. All available $P$. mirabilis genomes, including the $P$. mirabilis SCDR1 genome, were included in this analysis (Table 5). Results of our analysis (Table 6 and Fig. 8) showed that the number of the observed antimicrobial resistance based ontologies (AMRO) in $P$. mirabilis genomes is 61. Only 16 AMROs were observed amongst all the studied $56 P$. mirabilis genomes. Meanwhile, 13 AMROs were observed amongst 55 P. mirabilis genomes. In addition, only four AMROs were observed amongst 54 P. mirabilis genomes and two AMROs were observed amongst $48 \mathrm{P}$. mirabilis genomes. This suggests that the core constituent of antibiotic resistome of $P$. mirabilis species is made up of 35 AMROs (Table 6). On the other hand, eight AMROs were detected only in one $P$. mirabilis genome. For example, the membrane fusion component of tripartite multidrug resistance system was only observed in our P. mirabilis SCDR1 genome.

\section{Consensus $P$. mirabilis-SCDR1 antibiotic Resistome}

Table 7 displays the consensus $P$. mirabilis-SCDR1 antibiotic resistome. Genomics analysis of $P$. mirabilis-SCDR1 63 contigs showed that our isolates contained genetic determinants for tetracycline resistance (tetAJ), fluoroquinolones resistance (gyrA, parC and parE), sulfonamide resistance (folP), daptomycin and rifamycin resistance (rpoB), elfamycin antibiotics resistance (tufB), Chloramphenicol (cpxR, cpxA and cat), ethidium bromide-methyl viologen resistance protein (emrE) and polymyxin resistance (phoP). In addition, several multidrug resistance efflux systems and complexes such as MdtABC-TolC, MacAB-TolC, AcrABTolC, EmrAB-TolC, AcrEF-TolC and MATE.

\section{Heavy metal resistance}

Table 8 presents $P$. mirabilis SCDR1 heavy metal resistance/binding factors. Numerous genetic determinants for metal resistance were observed in the $P$. mirabilis SCDR1 genome. Several Copper resistance genes/proteins were detected, namely, copA, copB, copC, copD, cueO, cueR, cutC, cutF and CuRO_2_CopA_like1. In addition, gene determinants of Copper/silver efflux system were observed, namely, oprB, oprM and cusC_1. Moreover, several heavy metal resistance proteins and efflux systems were observed, such as magnesium/cobalt efflux protein CorC, metal resistance proteins (AGS59089.1, AGS59090.1 and AGS59091.1), nickel-cobalt-cadmium resistance protein $\mathrm{NccB}$, arsenical pump membrane protein (ArsB permease), Lead, cadmium, zinc and mercury transporting ATPase, outer membrane component of tripartite multidrug resistance system (CusC) and complete $P$. mirabilis tellurite resistance loci (terB, terA, terC, terD, terE, terZ). Furthermore, enzymes involved in heavy metal resistance were also observed such as glutathione S-transferase (gst1, gst, Delta and Uncharacterized), arsenite S-adenosylmethyltransferase (Methyltransferase type 11) and alkylmercury lyase (MerB). 


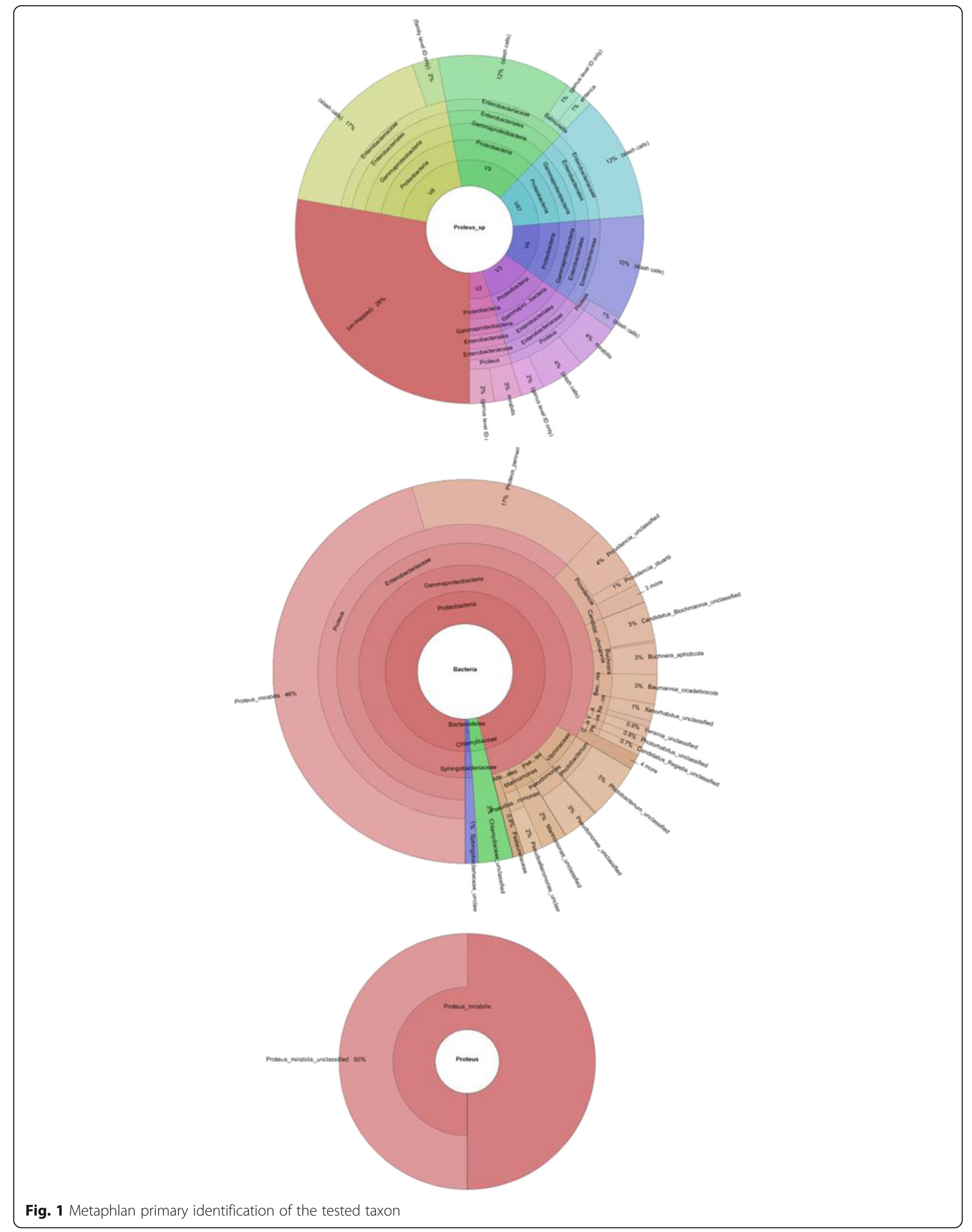


Table 4 Comparison of Proteus mirabilis SCDR1 to complete and draft reference genomes of Proteus mirabilis

\begin{tabular}{|c|c|c|c|c|c|c|c|}
\hline NCBI ID & Reference & Ref Size & Gaps sum length & Gaps $>=100 \mathrm{bp}$ & Bases sum length & Bases $>500 \mathrm{bp}$ & $\%$ Reference \\
\hline \multicolumn{8}{|l|}{ Completed Genomes } \\
\hline NC_010554.1 & Proteus mirabilis HI4320 & $4,063,606$ & 555,251 & 549,285 & $3,508,355$ & $3,472,919$ & 86.33 \\
\hline NC_010555.1 & $\begin{array}{l}\text { Proteus mirabilis plasmid } \\
\mathrm{pHI} 4320\end{array}$ & 36,289 & 36,289 & 36,289 & 0 & 0 & 0 \\
\hline NC_022000.1 & Proteus mirabilis BB2000 & $3,846,754$ & 304,708 & 298,947 & $3,542,046$ & $3,510,682$ & 92.07 \\
\hline \multicolumn{8}{|l|}{ Draft Genomes } \\
\hline NZ_ACLE00000000 & $\begin{array}{l}\text { Proteus mirabilis } \\
\text { ATCC_29,906 }\end{array}$ & $4,027,100$ & 565,180 & 560,679 & $3,461,920$ & $3,432,786$ & 85.96 \\
\hline NZ_ANBT00000000 & Proteus mirabilis C05028 & $3,817,619$ & 343,688 & 338,218 & $3,473,931$ & $3,445,432$ & 90.99 \\
\hline NZ_AORN00000000 & Proteus mirabilis PR03 & $3,847,612$ & 394,926 & 390,203 & $3,452,686$ & $3,430,536$ & 89.73 \\
\hline NZ_AMGU00000000 & Proteus mirabilis WGLW4 & $3,960,485$ & 474,704 & 469,864 & $3,485,781$ & $3,458,264$ & 88.01 \\
\hline NZ_AMGT00000000 & Proteus mirabilis WGLW6 & $4,101,891$ & 606,773 & 601,555 & $3,495,118$ & $3,461,467$ & 85.20 \\
\hline
\end{tabular}

\section{Discussion}

Proteus mirabilis isolate was observed as mixed culture along with $S$. aureus isolate while testing our produced silver Nanoparticles against several pathogenic S. aureus isolates [9]. Whereas other tested Gram positive and negative bacteria showed great sensitivity against silver Nanoparticles, P. mirabilis, SCDR1 isolate exhibited extreme resistance. $P$. mirabilis SCDR1 isolate resistant against at least one antibiotic belonging to ansamycins, glycopeptides, fucidanes, cyclic peptides, nitroimidazoles, macrolides, lincosamides, folate pathway inhibitors and aminocoumarin antimicrobial categories. Moreover, our isolate exhibited intrinsic resistance against tetracyclines and polymyxins specific to $P$. mirabilis species $[36,52,53]$. However, fortunately, our isolate was sensitive to several operational antimicrobial categories such as penicillins with b-lactamase inhibitors, extendedspectrum cephalosporins, carbapenems, aminoglycosides, fluoroquinolones and phosphonic acids. In addition, our P. mirabilis SCDR1 isolate showed high resistance against colloidal and composite Nanosilver and metallic silver when compared to other tested Gram positive and negative bacterial species, both qualitatively and quantitatively. To the best of our knowledge, this is the first reported case of bacterial spontaneous resistance to colloidal and composite nanosilver. However, Gunawan et al., (2013) reported the occurrence of induced adaptation, of non-targeted environmental Bacillus species to antimicrobial Nanosilver [14]. In addition, it was found that bacteria can straightforwardly develop resistance to AgNPs, and this occurs by relatively simple genomic changes [54]. They both showed that a Bacillus $s p$. environmental isolate and an E.coli isolate were able to adapt to Nanosilver cytotoxicity upon continued exposure. Nonetheless, as previously stated, P. mirabilis
SCDR1 exhibited instantaneous resistance against nanosilver without the need for any prolonged exposure. $P$. mirabilis SCDR1 demonstrated resistance against colloidal nanosilver assessed either by disk diffusion or by minimal inhibitory concentration methods. While all used concentrations of colloidal Nanosilver have shown strong effects on all tested microorganisms (Table 1), there was no effect on the bacterial growth of $P$. mirabilis SCDR1 even at the highest used concentration (200 ppm). Similarly, P. mirabilis SCDR1 was able to resist ten fold $(500 \mathrm{ppm})$ higher than $K$. pneumoniae (50 ppm), five fold higher than $P$. aeruginosa and E. coli (100 ppm) and two and a half fold (200 ppm) higher than S. aureus and E. cloacae (Table 2). Moreover, while both laboratory prepared and commercially available silver and Nanosilver composite showed a clear effect against both $S$. aureus and $P$. aeruginosa, the most common pathogens of diabetic foot ulcer, not effect was observed against $P$. mirabilis SCDR1 (Table 3). Although chitosan nanosilver composites have documented combined effect against both Gram positive and negative pathogens [37] no effect was observed against $P$. mirabilis SCDR1. Silver is a highly toxic element for microbes. The Nanosilver exhibits high surface to volume ratio, which shows increased antimicrobial power in comparison to the same bulk silver material [55]. It is suggested that the antimicrobial mechanism of silver ions involves the disruption of phospholipids of cytoplasmic, and the disruption of DNA replication, impairing the function of ribosomes to transcribe messenger RNA and/or inactivation of cytochrome b by binding with sulfhydryl group [56]. P. mirabilis SCDR1 genome analysis showed that our isolate contains a large number of genes (245) responsible for xenobiotics biodegradation and metabolism (Additional file 2: Table S2). 


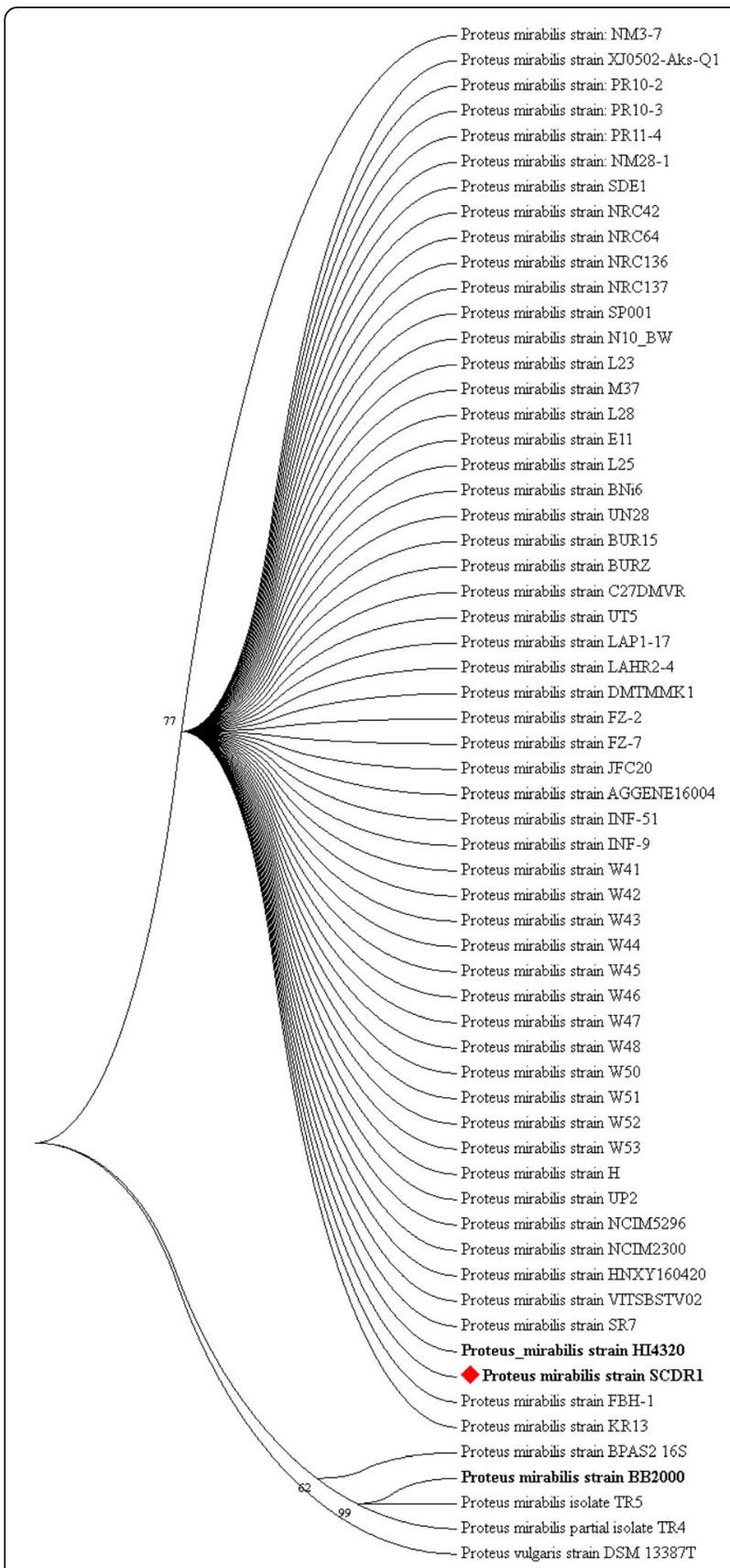

Fig. 2 16S rDNA based Maximum likelihood phylogenetic tree of Proteus mirabilis spices including Pm-SCDR1 isolate

Although P. mirabilis SCDR1 does not contain the chitinase genes responsible for Chitin and chitosan degradation, it contained Chitin binding protein (cbp, 203 amino acid protein). This may justify the ability of $P$. mirabilis SCDR1 to resist the antimicrobial effect of chitosan. Chitin-binding protein even without any catalytic domain can facilitate the degradation of $\beta$-chitin by means of disrupting the crystalline chitin polymer structure [57, 58]. Microbial ability to produce proteins with high specific affinity to a certain crystalline chitin structure could be pivotal for the capability of bacteria to differentiate and react to specific crystalline chitin structures [59]. In addition, these chitin-binding domains may affect chitin degradation by facilitating adhesion of cells to the chitinous materials [57]. Thus, although we did not detect chitinase genes in P. mirabilis SCDR1, the presence of Chitin-binding protein suggests that $P$. mirabilis SCDR1 has some mechanisms of protection against chitin and the chitosan antimicrobial effect. In addition, the presence of genes encoding for the members Chitosanase family $\mathrm{GH} 3$ of $\mathrm{N}, \mathrm{N}^{\prime}$-diacetylchitobiose-specific 6-phospho-beta-glucosidase (EC 3.2.1.86), Beta $\mathrm{N}$-acetyl-glucosaminidase (nagZ, betahexosaminidase) (EC 3.2.1.52), and Glucan endo-1, 4beta-glucosidase (EC 3.2.1.-) in P. mirabilis SCDR1 suggests that it can hydrolyze chitosan to glucosamine [60-62]. This justifies the lack of antimicrobial effect of chitosan against $P$. mirabilis SCDR1. Likewise, $P$. mirabilis SCDR1 showed resistance against all the tested commercially available silver and Nanosilver containing wound dressing bandages. These silver containing commercially available bandages (wound dressing material) use different manufacturing technology and constituents. For example, Silvercel wound dressing contains high $\mathrm{G}$ calcium alginate in addition to $28 \%$ Silver-coated fibers (dressing contains $111 \mathrm{mg}$ silver/100 $\mathrm{cm}^{2}$ ). The silver-coated fibers encompass elemental silver, which is converted to silver oxide upon contact with oxygen. Silver oxide dissolves in fluid and releases ionic silver $\left(\mathrm{Ag}^{+}\right)$that has antimicrobial action [63]. Clinical studies showed that Silvercel wound dressing is effective against many common wound pathogens, including methicillinresistant Staphylococcus aureus (MRSA), methicillin -resistant Staphylococcus epidermidis (MRSE) and vancomycin-resistant Enterococcus (VRE). In addition, these studies showed that Silvercel wound dressing prevented and disrupted the formation of bacterial biofilms [64, 65]. However, this was not the case with our P. mirabilis SCDR1 isolate. Similarly, Sorbsan Silver wound dressing which is made of the fiber of the calcium salt of the alginic acid that contains $1.5 \%$ silver [66-68] did not show any antimicrobial effect against $P$. mirabilis SCDR1 isolate. Likewise, Colactive ${ }^{\bullet}$ Plus Ag, which is a silver impregnated collagenbased /alginate foam sheet wound dressing, did not show any antimicrobial effect against $P$. mirabilis SCDR1 isolate. In addition, Exsalt ${ }^{\circ}$ SD7 is a silver wound dressing that uses silver oxysalts technology. Silver oxysalts offer greater oxidation states of silver* 


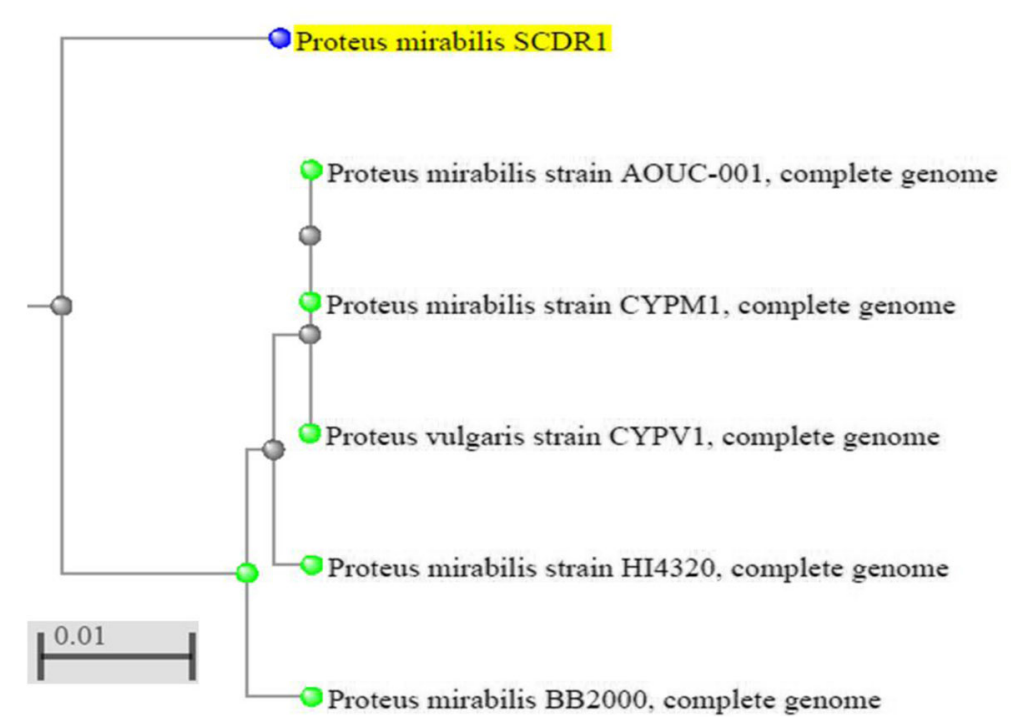

Fig. 3 Whole genome Neighbor joining phylogenetic tree of Proteus mirabilis spices including Pm-SCDR1 isolate

$\left(\mathrm{Ag}^{2+}, \mathrm{Ag}^{3+}\right)$ capable of interacting with microbial DNA, proteins and lipids, as well as providing potent oxidizing action through the increased power of Ag2 ${ }^{+, 3+}$ for advanced biocidal activity. Exsalt ${ }^{\circ} \mathrm{SD} 7$ showed high antimicrobial activity against tested Gramnegative and positive bacteria and fungi tested [69]. $P$. mirabilis SCDR1 isolate showed high resistance against Exsalt ${ }^{\circ}$ SD7. In addition, $P$. mirabilis SCDR1 isolate showed high resistance against Puracol ${ }^{\bullet}$ Plus Ag, which is made of $100 \%$ Collagens in addition to antimicrobial silver. Furthermore, Actisorb ${ }^{\circ}$ Silver 220, which is a sterile primary dressing encompassing an activated charcoal cloth, impregnated with silver within a spun bonded perforated nylon sleeve [70] was not active against $P$. mirabilis SCDR1 isolate.

Pathogenomics analysis showed that $P$. mirabilis SCDR1 isolate is a potential virulent pathogen (Additional files 3 and 4: Tables 3 and 4). P. mirabilis SCDR1 shows that it possesses the characteristic bull's eye pattern of swarming behavior. Presenting swarmer cells form is associated with the increase in expression of virulence genes [71]. Swarming is important to $P$. mirabilis uropathogenesis. It has been shown that swarming bacteria that move in multicellular groups exhibit adaptive resistance to multiple antibiotics [72]. Swarming behavior promotes the survival of bacteria in harsh environments or in unfavorable conditions. Moreover, migrating swarm cells display an increased resistance to many of antimicrobial agents. Therefore antimicrobial resistance could be a general feature of bacterial multicellular social behavior [73]. For example, the swarm cells of $P$. aeruginosa were able to migrate very close to the disc containing arsenite, indicating resistance to this heavy metal [73]. It has been suggested that high densities promote bacterial survival, the ability to move, as well as the speed of movement, confers an added advantage, making swarming an effective strategy for prevailing against antimicrobials including heavy metals [72, 73]. Furthermore, altruism or self-sacrifice is a suggested phenomenon associated with swarming, which involves risk of wiping out some individuals upon movement of bacteria to a different location, allowing the remaining individuals to continue their quest [72, 74]. Another suggested phenomenon associated with swarming is selfish behavior, in which the survival may be highest on top cells that are furthest from the antimicrobial agent while the lower cells in the swarm die because of the proximity to antimicrobial agents [72, $75]$. Thus, selfish cells within the swarm sense where the best location is to avoid the toxic effect of the antimicrobial agent. Swarming behavior may indeed be one main reason for the observed nanosilver resistance of $P$. mirabilis SCDR1. Thus, maintaining high cell density, through the observed quorum sensing ability (Additional file 4: Table S4) and the circulation within the multilayered colony to minimize exposure to the heavy metal in addition to the death of individuals that are directly exposed, could be the key to the observed nanosilver resistance.

P. mirabilis SCDR1 isolate exhibited the ability of biofilm formation and also our pathogenomics analysis showed that it contains the genes responsible for this, 
a
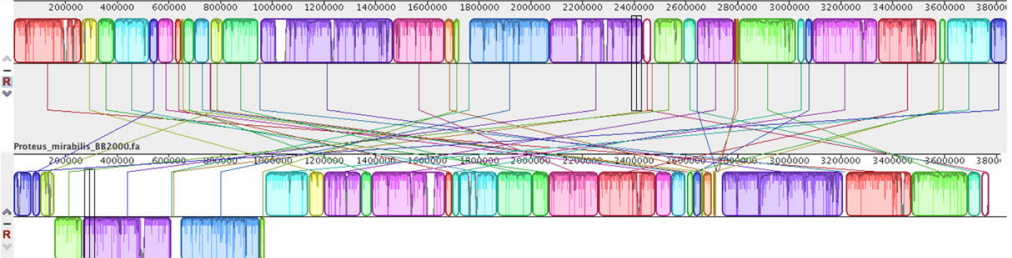

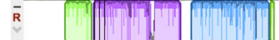

Proters m. miablis scortatatas

b

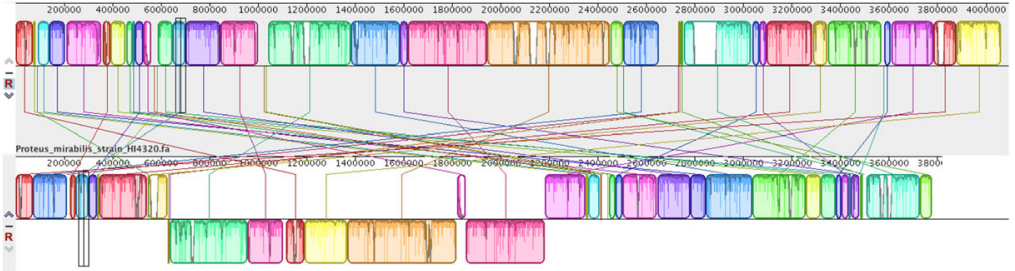

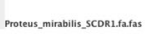

C

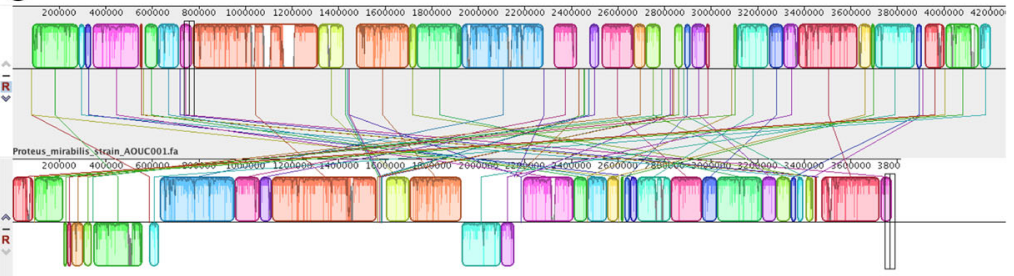

d

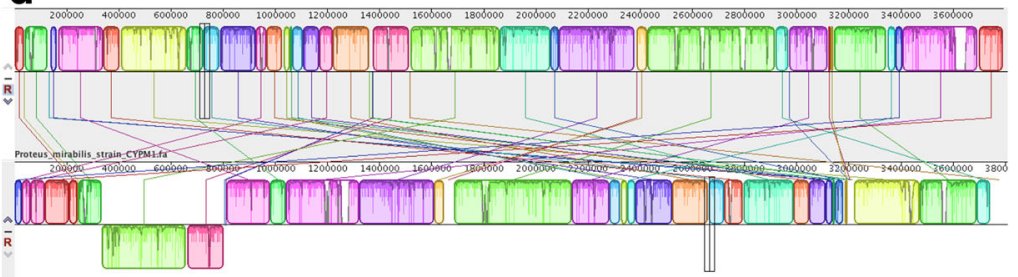

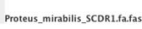

e
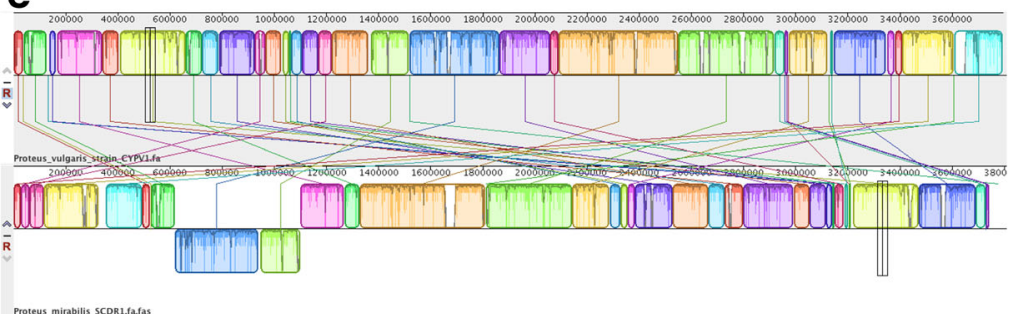

f

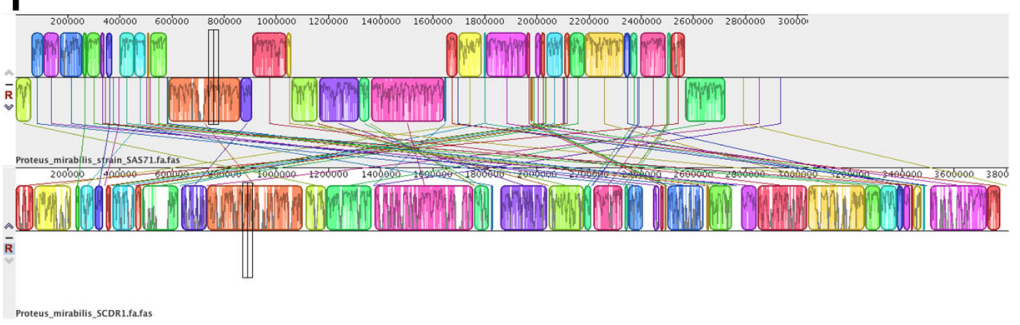

Fig. 4 (See legend on next page.) 
(See figure on previous page.)

Fig. 4 Pair-wise Whole Genome Alignment of $P$. mirabilis strain SCDR1 against reference genomes. a $P$. mirabilis BB200 and P. mirabilis SCDR1 Mauve whole genome alignment, b P. mirabilis HI4320 and P. mirabilis SCDR1, c P. mirabilis AOUC001 and P. mirabilis SCDR1, d P. mirabilis CYPM1 and $P$. mirabilis SCDR1, e $P$. vulgaris CYPV1 and $P$. mirabilis SCDR1, f $P$. mirabilis SAS71 and $P$. mirabilis SCDR1 Mauve whole genome alignment

such as glpC gene coding for anaerobic glycerol-3phosphate dehydrogenase subunit C (EC 1.1.5.3), pmrI gene coding for UDP-glucuronic acid decarboxylase and baaS gene coding for biofilm formation regulatory protein BssS. We believe that the ability of $P$. mirabilis SCDR1 to form biofilm may also assist in the observed Nanosilver resistance. Biofilm formation can reduce the metal toxic effect by trapping it outside the cells. It was found that in the relative bacteria Proteus vulgaris XC 2, the biofilm cells showed considerably greater resistance to Chloromycetin compared to planktonic cells (freefloating counterparts) [76]. Moreover, it is suggested that the ability of biofilm formation may play a pivotal role in Polymyxin B antibiotic resistance in P. mirabilis [77]. Furthermore, it was found that biofilm formation is very important for heavy metal resistance in Pseudomonas $s p$. and that a biofilm lacking mutant was less tolerant to heavy metals [78]. Furthermore, it was found that both Extracellular Polysaccharides and Biofilm Formation is a resistance mechanism against toxic metals in Sinorhizobium meliloti, the nitrogen-fixing bacterium [79]. In addition, several reports claimed that the minimum inhibitory concentration (MIC) of some antibiotics for biofilms can be 1000 -fold higher than that for planktonic bacteria [80].

It is well known that there are several mechanisms for metal resistance. These include physicochemical interactions, efflux, intracellular sequestration and extracellular precipitation by the excreted polymeric compounds [79]. Indeed, additional to swarming activity, Polysaccharides and biofilm formation (Additional file 4: Table S4), $P$. mirabilis SCDR1 contains several genes and proteins that also facilitate metal resistance including silver and Nanosilver (Table 8). Our results indicate the presence

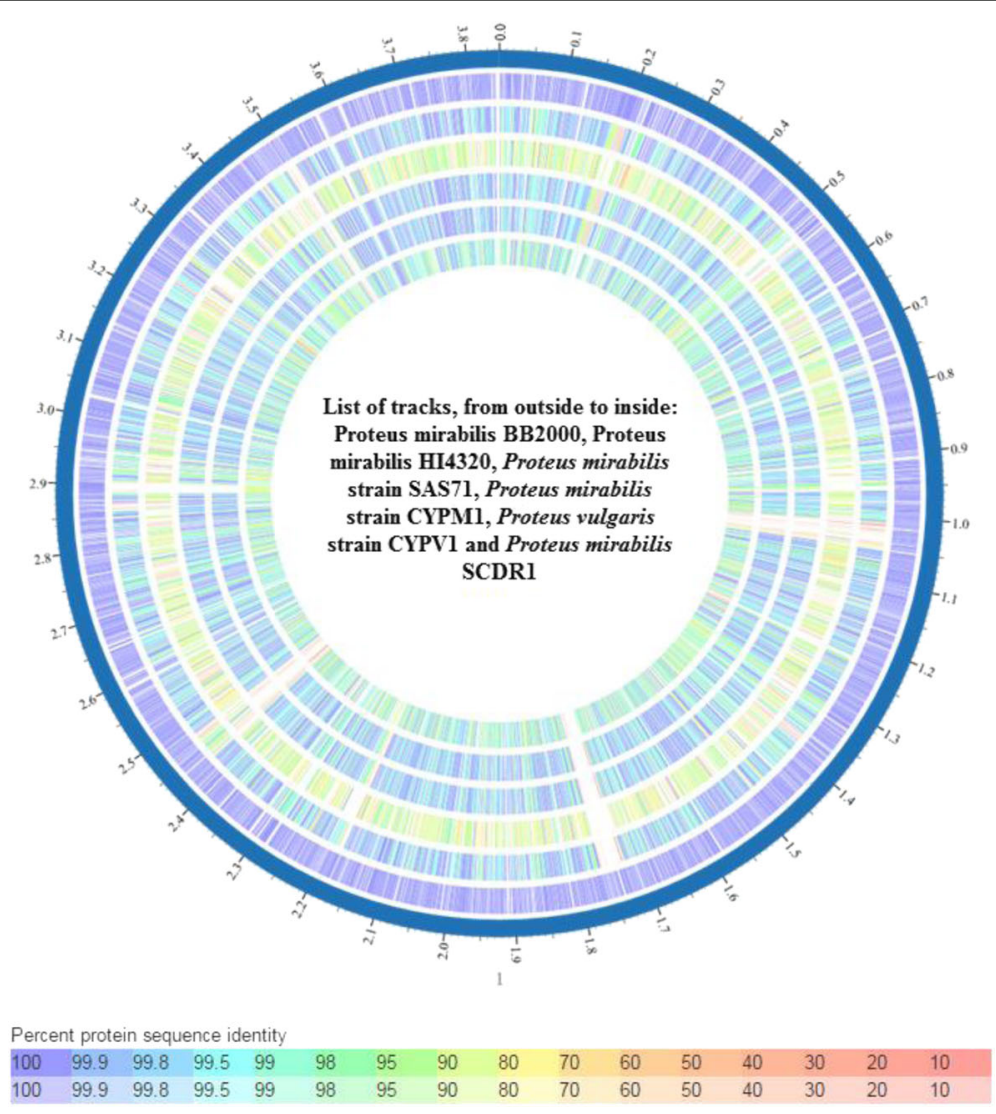

Fig. 5 Whole genome phylogeny based proteomic comparison among Proteus mirabilis strains 


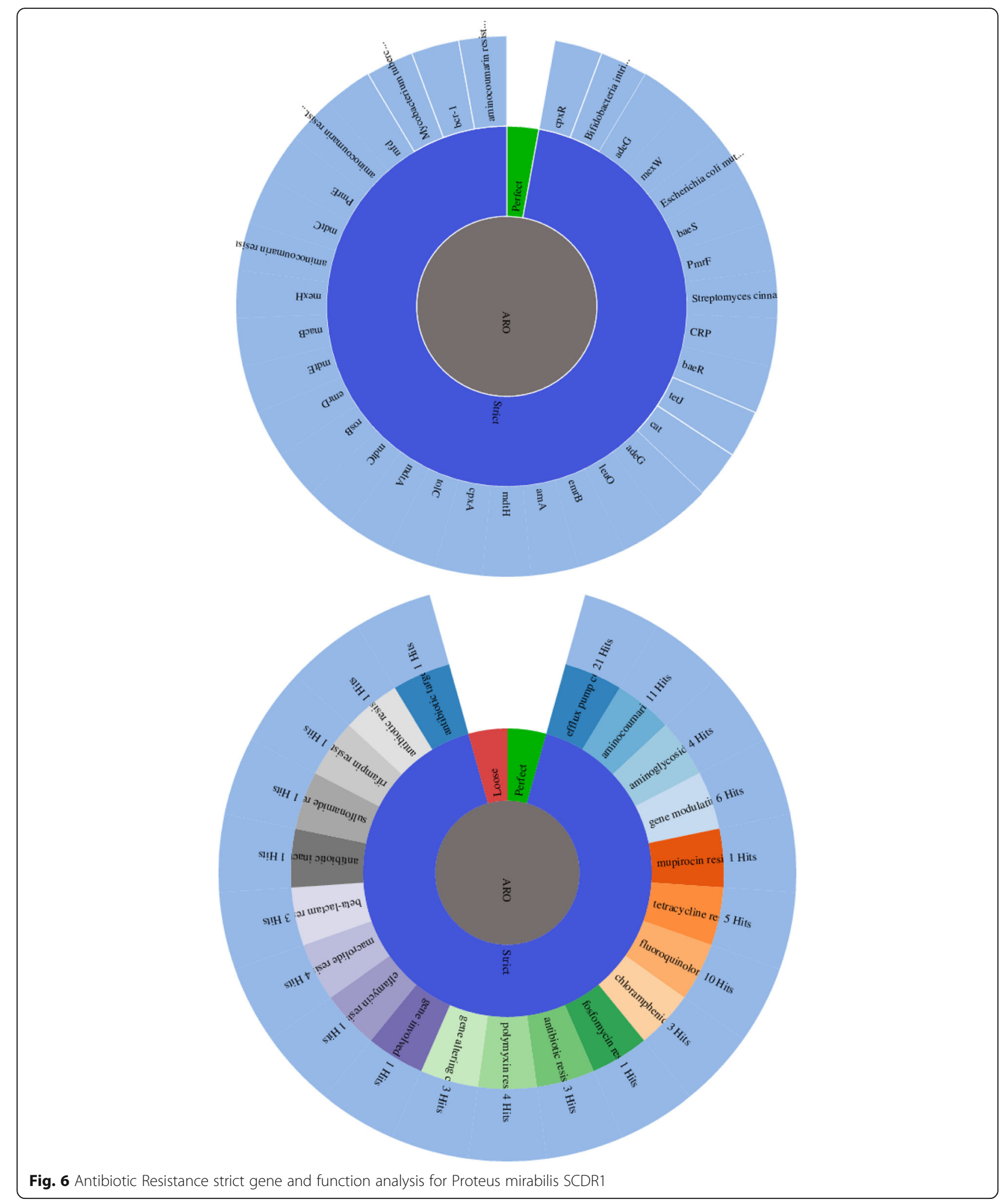

of endogenous silver and copper resistance mechanism in P. mirabilis SCDR1. We observed the presence of gene determinants of Copper/silver efflux system, oprB encoding for Copper/silver efflux system outer membrane protein $\mathrm{CusC}$ (outer membrane efflux protein OprB), oprM encoding for Copper/silver efflux system 


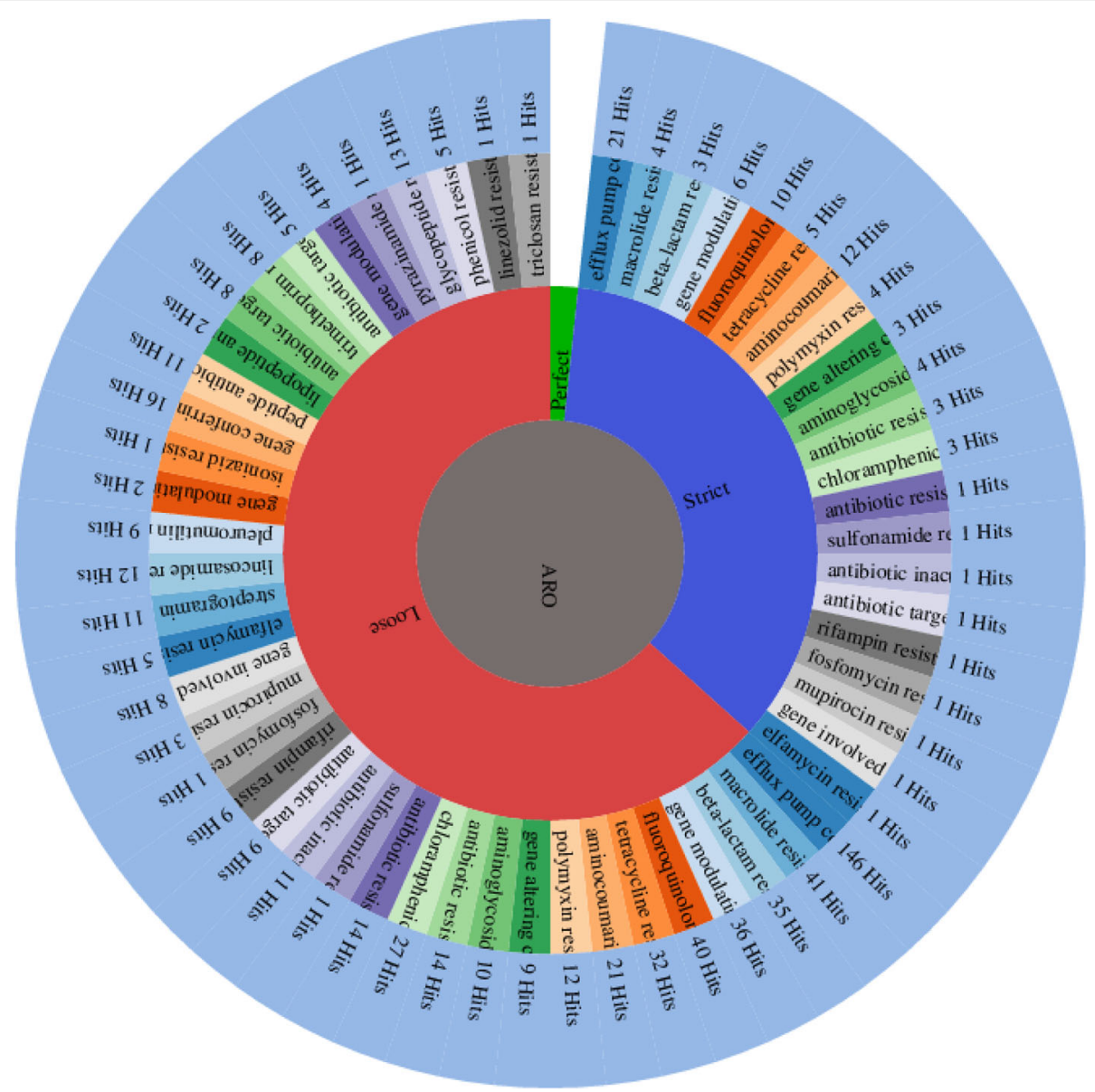

Fig. 7 Antibiotic Resistance lose functional categories analysis for Proteus mirabilis SCDR1

outer membrane protein CusC (outer membrane efflux protein OprM), cusC_1 encoding for Copper/silver efflux system outer membrane protein CusC (RND efflux system outer membrane lipoprotein), cpxA encoding for Copper sensory histidine kinase and outer membrane component of tripartite multidrug resistance system (CusC). In addition, we observed the presence of several Copper resistance genes/proteins were detected, namely, copA, copB, copC, copD, cueO, cueR, cutC, cutF and CuRO_2_CopA_like1. A similar endogenous silver and copper resistance mechanism has been described in $E$. coli and has been associated with the loss of porins from the outer membrane and up-regulation of the native Cus efflux mechanism, which is capable of transporting silver out of the cell $[81,82]$. However, the genetic basis resistant phenotypes are still not fully known, and it is not known if they are obligatory or sufficient to exhibit resistance to silver [83]. Thus, we suggest a comprehensive study for this endogenous silver resistance mechanism within the Proteus mirabilis as well as E. coli.
Furthermore, we observed the presence of genes encoding to enzymes involved in heavy metal resistance such as Glutathione S-transferase (EC 2.5.1.18) (gst1, gst, Delta and Uncharacterized) in P. mirabilis SCDR1 genome. Thus, we propose a role of Glutathione Stransferases of $P$. mirabilis SCDR1 in the observed Nanosilver resistance. Glutathione S-transferases (GSTs) are a family of multifunctional proteins that play an important role in the detoxification of harmful physiological and xenobiotic compounds in organisms [84]. Moreover, it was found that a Glutathione Stransferase is involved in copper, cadmium, Lead and mercury resistance [85]. Furthermore, it was found that GST genes are differentially expressed in defense against oxidative stress caused by $\mathrm{Cd}$ and Nanosilver exposure [85].

Moreover, we observed the presence of a complete tellurite resistance operon (terB, terA, terC, terD, terE, terZ) which was suggested as contributing to virulence or fitness and protection from other forms of oxidative 
Table 5 Proteus mirabilis genomes represented in the species wide comparative genomics antibiotic resistance analysis

\begin{tabular}{|c|c|c|}
\hline $\begin{array}{l}\text { Genome/Strain } \\
\text { Name }\end{array}$ & $\begin{array}{l}\text { Genome } \\
\text { Status }\end{array}$ & GenBank Accessions \\
\hline $\begin{array}{l}\text { P. mirabilis } \\
\text { ATCC } 29906\end{array}$ & WGS & ACLE00000000 \\
\hline $\begin{array}{l}\text { P. mirabilis } \\
\text { BB2000 }\end{array}$ & Complete & СР004022.1 \\
\hline $\begin{array}{l}\text { P. mirabilis } \\
\text { C05028 }\end{array}$ & WGS & ANBT00000000 \\
\hline $\begin{array}{l}\text { P. mirabilis } \\
\mathrm{HI} 4320\end{array}$ & Complete & AM942759,AM942760 \\
\hline $\begin{array}{l}\text { P. mirabilis } \\
\text { PR03 }\end{array}$ & WGS & AORN00000000 \\
\hline $\begin{array}{l}\text { P. mirabilis } \\
\text { SCDR1 }\end{array}$ & WGS & LUFT00000000 \\
\hline $\begin{array}{l}\text { P. mirabilis } \\
\text { WGLW4 }\end{array}$ & WGS & AMGU00000000 \\
\hline $\begin{array}{l}\text { P. mirabilis } \\
\text { WGLW6 }\end{array}$ & WGS & AMGT00000000 \\
\hline $\begin{array}{l}\text { P. mirabilis } \\
\text { strain } \\
\text { 1114_PMIR }\end{array}$ & WGS & JWCS01000000 \\
\hline $\begin{array}{l}\text { P. mirabilis } \\
\text { strain } \\
\text { 1134_PMIR }\end{array}$ & WGS & JWBY01000000 \\
\hline $\begin{array}{l}\text { P. mirabilis } \\
\text { strain } \\
1150 \_ \text {PMIR }\end{array}$ & WGS & JWBG01000000 \\
\hline $\begin{array}{l}\text { P. mirabilis } \\
\text { strain } \\
\text { 1166_PMIR }\end{array}$ & WGS & JWAP01000000 \\
\hline $\begin{array}{l}\text { P. mirabilis } \\
\text { strain } \\
\text { 127_PMIR }\end{array}$ & WGS & JWWE01000000 \\
\hline $\begin{array}{l}\text { P. mirabilis } \\
\text { strain } \\
\text { 1293_PMIR }\end{array}$ & WGS & JWD01000000 \\
\hline $\begin{array}{l}\text { P. mirabilis } \\
\text { strain } \\
\text { 1310_PMIR }\end{array}$ & WGS & JVUH01000000 \\
\hline $\begin{array}{l}\text { P. mirabilis } \\
\text { strain } \\
\text { 1313_PMIR }\end{array}$ & WGS & JVUE01000000 \\
\hline $\begin{array}{l}\text { P. mirabilis } \\
\text { strain } \\
\text { 1326_PMIR }\end{array}$ & WGS & JVTO01000000 \\
\hline $\begin{array}{l}\text { P. mirabilis } \\
\text { strain } \\
\text { 1330_PMIR }\end{array}$ & WGS & JVTJ01000000 \\
\hline $\begin{array}{l}\text { P. mirabilis } \\
\text { strain } \\
\text { 232_PMIR }\end{array}$ & WGS & JVPB01000000 \\
\hline $\begin{array}{l}\text { P. mirabilis } \\
\text { strain } \\
25,933 \text { GTA }\end{array}$ & WGS & LANL01000000 \\
\hline $\begin{array}{l}\text { P. mirabilis } \\
\text { strain } \\
25 \text { PMIR }\end{array}$ & WGS & JVOK01000000 \\
\hline
\end{tabular}

Table 5 Proteus mirabilis genomes represented in the species wide comparative genomics antibiotic resistance analysis (Continued)

\begin{tabular}{|c|c|c|}
\hline $\begin{array}{l}\text { Genome/Strain } \\
\text { Name }\end{array}$ & $\begin{array}{l}\text { Genome } \\
\text { Status }\end{array}$ & GenBank Accessions \\
\hline $\begin{array}{l}\text { P. mirabilis } \\
\text { strain } \\
\text { 292_PMIR }\end{array}$ & WGS & JVMQ01000000 \\
\hline $\begin{array}{l}\text { P. mirabilis } \\
\text { strain } \\
\text { 360_PMIR }\end{array}$ & WGS & JVKD01000000 \\
\hline $\begin{array}{l}\text { P. mirabilis } \\
\text { strain } \\
\text { 373_PMIR }\end{array}$ & WGS & JVJQ01000000 \\
\hline $\begin{array}{l}\text { P. mirabilis } \\
\text { strain } \\
418 \text { PMIR }\end{array}$ & WGS & JVHX01000000 \\
\hline $\begin{array}{l}\text { P. mirabilis } \\
\text { strain } \\
429 \text { PMIR }\end{array}$ & WGS & JVHK01000000 \\
\hline $\begin{array}{l}\text { P. mirabilis } \\
\text { strain } \\
430 \_ \text {PMIR }\end{array}$ & WGS & JVHI01000000 \\
\hline $\begin{array}{l}\text { P. mirabilis } \\
\text { strain } \\
\text { 47_PMIR }\end{array}$ & WGS & JVFU01000000 \\
\hline $\begin{array}{l}\text { P. mirabilis } \\
\text { strain } \\
50,664,164\end{array}$ & WGS & LNHT01000000 \\
\hline $\begin{array}{l}\text { P. mirabilis } \\
\text { strain } \\
\text { 51_PMIR }\end{array}$ & WGS & JVEH01000000 \\
\hline $\begin{array}{l}\text { P. mirabilis } \\
\text { strain } \\
\text { 646_PMIR }\end{array}$ & WGS & JUYT01000000 \\
\hline $\begin{array}{l}\text { P. mirabilis } \\
\text { strain } \\
672 \text { PMIR }\end{array}$ & WGS & JUXR01000000 \\
\hline $\begin{array}{l}\text { P. mirabilis } \\
\text { strain } \\
\text { 68_PMIR }\end{array}$ & WGS & JUXK01000000 \\
\hline $\begin{array}{l}\text { P. mirabilis } \\
\text { strain } \\
\text { AOUC-001 }\end{array}$ & Complete & СР015347 \\
\hline $\begin{array}{l}\text { P. mirabilis } \\
\text { strain } \\
\text { ATCC } 7002\end{array}$ & WGS & JOVJ00000000 \\
\hline $\begin{array}{l}\text { P. mirabilis } \\
\text { strain } \\
\text { C02011 }\end{array}$ & WGS & $\begin{array}{l}\text { KV388086,KV388087,KV388088, } \\
\text { KV388089,KV388090,KV388091, } \\
\text { KV388092,LAGU00000000 }\end{array}$ \\
\hline $\begin{array}{l}\text { P. mirabilis } \\
\text { strain CYPM1 }\end{array}$ & Complete & СР012674 \\
\hline $\begin{array}{l}\text { P. mirabilis } \\
\text { strain } \\
\text { FDAARGOS } 60\end{array}$ & Complete & JTBW01000000 \\
\hline $\begin{array}{l}\text { P. mirabilis } \\
\text { strain } \\
\text { FDAARGOS } 67\end{array}$ & Complete & JTBP01000000 \\
\hline
\end{tabular}


Table 5 Proteus mirabilis genomes represented in the species wide comparative genomics antibiotic resistance analysis (Continued)

\begin{tabular}{|c|c|c|}
\hline $\begin{array}{l}\text { Genome/Strain } \\
\text { Name }\end{array}$ & $\begin{array}{l}\text { Genome } \\
\text { Status }\end{array}$ & GenBank Accessions \\
\hline $\begin{array}{l}\text { P. mirabilis } \\
\text { strain } \\
\text { FDAARGOS } 80\end{array}$ & WGS & JTBB01000000 \\
\hline $\begin{array}{l}\text { P. mirabilis } \\
\text { strain } \\
\text { FDAARGOS } 81\end{array}$ & Complete & JTBA01000000 \\
\hline $\begin{array}{l}\text { P. mirabilis } \\
\text { strain } \\
\text { FDAARGOS } 85\end{array}$ & WGS & JTAW01000000 \\
\hline $\begin{array}{l}\text { P. mirabilis } \\
\text { strain GB08 }\end{array}$ & WGS & LQNN00000000 \\
\hline $\begin{array}{l}\text { P. mirabilis } \\
\text { strain GB11 }\end{array}$ & WGS & LQNO00000000 \\
\hline $\begin{array}{l}\text { P. mirabilis } \\
\text { strain } \\
\text { GED7834 }\end{array}$ & WGS & $\begin{array}{l}\text { KQ960957,KQ960958,KQ960959,KQ960960, } \\
\text { KQ960961,KQ960962,KQ960963,KQ960964, } \\
\text { KQ960965,KQ960966,KQ960967,KQ960968, } \\
\text { KQ960969,KQ960970,KQ960971,KQ960972, } \\
\text { KQ960973,KQ960974,KQ960975,KQ960976, } \\
\text { KQ960977,KQ960978,KQ960979,KQ960980, } \\
\text { KQ960981,KQ960982,KQ960983,KQ960984, } \\
\text { KQ960985,KQ960986,KQ960987,KQ960988, } \\
\text { KQ960989,KQ960990,KQ960991,KQ960992, } \\
\text { KQ960993,KQ960994,KQ960995,KQ960996, } \\
\text { KQ960997,KQ960998,KQ960999,KQ961000, } \\
\text { KQ961001,KQ961002,KQ961003,KQ961004 } \\
\text {,KQ961005,KQ961006,KQ961007,KQ961008, } \\
\text { KQ961009,KQ961010,KQ961011,KQ961012, } \\
\text { KQ961013,KQ961014,KQ961015,KQ961016, } \\
\text { KQ961017,KQ961018 }\end{array}$ \\
\hline P. mirabilis & WGS & LQQZ00000000 \\
\hline strain M16 & & \\
\hline $\begin{array}{l}\text { P. mirabilis } \\
\text { strain } \\
\text { NIVEDI3-PG74 }\end{array}$ & WGS & LWDB00000000 \\
\hline $\begin{array}{l}\text { P. mirabilis } \\
\text { strain } \\
\text { NO-051/03 }\end{array}$ & WGS & LGAY01000000 \\
\hline $\begin{array}{l}\text { P. mirabilis } \\
\text { strain PM593 }\end{array}$ & WGS & JSUP01000000 \\
\hline $\begin{array}{l}\text { P. mirabilis } \\
\text { strain PM655 }\end{array}$ & WGS & JSUO01000000 \\
\hline $\begin{array}{l}\text { P. mirabilis } \\
\text { strain PM_125 }\end{array}$ & WGS & LWUL00000000 \\
\hline $\begin{array}{l}\text { P. mirabilis } \\
\text { strain PM_178 }\end{array}$ & WGS & LWUM00000000 \\
\hline $\begin{array}{l}\text { P. mirabilis } \\
\text { strain } \\
\text { Pm-Oxa48 }\end{array}$ & WGS & JSCB01000000 \\
\hline $\begin{array}{l}\text { P. mirabilis } \\
\text { strain Pr2921 }\end{array}$ & WGS & LGTA00000000 \\
\hline $\begin{array}{l}\text { P. mirabilis } \\
\text { strain SAS71 }\end{array}$ & WGS & LDIU01000000 \\
\hline $\begin{array}{l}\text { P. mirabilis } \\
\text { strain Wood }\end{array}$ & WGS & LTBK00000000 \\
\hline
\end{tabular}

stress or agents causing membrane damage, such as silver and Nanosilver, in P. mirabilis [86]. Several other heavy metal resistance genes and proteins were observed in the $P$. mirabilis SCDR1 genome. These included arsM encoding for arsenite S-adenosylmethyltransferase (Methyltransferase type 11), which play an important role in prokaryotic resistance and detoxification mechanism to arsenite $[87,88]$ and merB encoding for alkylmercury lyase that cleaves the carbon-mercury bond of organomercurials, such as phenylmercuric acetate [89]. Moreover, numerous heavy metal resistance proteins were observed, such as magnesium/cobalt efflux protein CorC, metal resistance proteins, nickel-cobalt-cadmium resistance protein NccB, arsenical pump membrane protein (ArsB permease), Lead, cadmium, zinc and mercury transporting ATPase (Table 8).

In order to gain information about antimicrobial resistome constituents in $P$. mirabilis species, we performed comparative genomics analysis amongst all available $56 P$. mirabilis genomes, including the $P$. mirabilis SCDR1 genome. As stated before, all $P$. mirabilis genomes shared 16 AMROs (Table 6). For example, all genomes contained the AMRO of copper sensory histidine kinase CpxA in cpxA mutant confer resistant to amikacin, copper-sensing twocomponent system response regulator $\mathrm{CpxR}$, which is a regulator that promotes acrD expression when phosphorylated by a cascade involving CpxA, a sensor kinase and linked to cefepime and chloramphenicol resistance in Klebsiella pneumoniae [90]. However, different $P$. mirabilis genomes varied in the remaining 45 studied AMRO (Table 6). For example, genomics analysis of $P$. mirabilis-SCDR1 showed that our isolates contained genetic determinants for fluoroquinolones resistance (gyrA, parC and parE) [91, 92], Daptomycin and Rifamycin resistance (rpoB) [93], Chloramphenicol (cpxR, cpxA and cat) $[90,94]$, Ethidium bromide-methyl viologen resistance protein (emrE) [95] and Polymyxin and colistin resistance (phoP) [96]. In addition, several multidrug resistance efflux systems and complexes were observed. These include MdtABC-TolC, which is a multidrug efflux system in Gram-negative bacteria, including E. coli and Salmonella that confer resistance against $\beta$-lactams, novobiocin and deoxycholate. It is noteworthy that MdtABC-TolC and AcrD plays a role in metal resistance (copper and zinc), along with their BaeSR regulatory system [97] which was also was found in our P. mirabilis SCDR1 genome [Table 7], and thus may also play an additional role in silver resistance. MdtABC-TolC contains MdtA, which is a membrane fusion protein, TolC, which is the outer membrane channel and 
Table 6 Species wide Proteus mirabilis antibiotic resistome constituents

\begin{tabular}{|c|c|}
\hline Antimicrobial Resistance based ontology (AMRO) & Number of Genomes shared AMRO \\
\hline 6'-N-acetyltransferase & 4 \\
\hline Aminoglycoside 3'-phosphotransferase @ Streptomycin 3'-kinase StrA & 13 \\
\hline Aminoglycoside 3'-phosphotransferase & 16 \\
\hline Putative transport protein ARO:3,001,215, ARO:1,000,001 & 48 \\
\hline Beta-lactamase & 14 \\
\hline Bicyclomycin resistance protein & 3 \\
\hline Chloramphenicol acetyltransferase & 54 \\
\hline COG0488: ATPase components of ABC transporters with duplicated ATPase domains & 1 \\
\hline Copper sensory histidine kinase CpxA & 56 \\
\hline Copper-sensing two-component system response regulator CpxR & 56 \\
\hline Cyclic AMP receptor protein & 56 \\
\hline Dihydropteroate synthase & 56 \\
\hline Dihydropteroate synthase type-2 @ Sulfonamide resistance protein & 16 \\
\hline DNA gyrase subunit A & 56 \\
\hline DNA-binding protein H-NS & 55 \\
\hline DNA-directed RNA polymerase beta subunit & 56 \\
\hline Ethidium bromide-methyl viologen resistance protein EmrE & 55 \\
\hline Gentamicin 3'-N-acetyltransferase & 2 \\
\hline Hypothetical protein ARO: 3,000,230, ARO: 1,000,001 & 2 \\
\hline Streptomycin 3"-O-adenylyltransferase @ Spectinomycin 9-O-adenylyltransferase & 5 \\
\hline Macrolide export ATP-binding/permease protein MacB & 56 \\
\hline Macrolide-specific efflux protein MacA & 55 \\
\hline Membrane fusion component of tripartite multidrug resistance system & 1 \\
\hline MFS superfamily export protein YceL & 55 \\
\hline Mobile element protein ARO: 3,000,903, ARO: 1,000,001 & 9 \\
\hline $\begin{array}{l}\text { Multi antimicrobial extrusion protein (Na (+)/drug antiporter), MATE family } \\
\text { of MDR efflux pumps }\end{array}$ & 56 \\
\hline Multidrug resistance protein D. ARO: 3,000,309, ARO: 1,000,001 & 56 \\
\hline Multidrug resistance protein ErmA & 55 \\
\hline Multidrug resistance protein ErmB & 56 \\
\hline Multidrug transporter MdtB & 56 \\
\hline Multidrug transporter MdtC & 56 \\
\hline Multidrug-efflux transporter, major facilitator superfamily (MFS) & 54 \\
\hline N-3-oxohexanoyl-L-homoserine lactone quorum-sensing transcriptional activator & 1 \\
\hline Outer membrane porin OmpF & 54 \\
\hline Outer membrane protein $\mathrm{F}$ precursor & 1 \\
\hline Probable RND efflux membrane fusion protein & 1 \\
\hline Putative transport protein ARO: 3,001,215, ARO: 1,000,001 & 48 \\
\hline Redox-sensitive transcriptional activator SoxR & 55 \\
\hline Response regulator BaeR & 56 \\
\hline Ribosomal RNA methyltransferase & 1 \\
\hline Rifampin ADP-ribosyl transferase & 3 \\
\hline RND efflux system, inner membrane transporter ARO: 3,000,216, ARO: 1,000,001 & 2 \\
\hline
\end{tabular}


Table 6 Species wide Proteus mirabilis antibiotic resistome constituents (Continued)

\begin{tabular}{|c|c|}
\hline Antimicrobial Resistance based ontology (AMRO) & Number of Genomes shared AMRO \\
\hline $\begin{array}{l}\text { RND efflux system, inner membrane transporter: Aminoglycoside, } \\
\text { Glycylcycline, Beta_lactam, Macrolide, Acriflavin }\end{array}$ & 3 \\
\hline $\begin{array}{l}\text { RND efflux system, inner membrane transporter Aminoglycoside, Glycylcycline, } \\
\text { Beta_lactam, Macrolide, Acriflavin ARO: 3,000,216, ARO: 1,000,001 }\end{array}$ & 3 \\
\hline $\begin{array}{l}\text { RND efflux system, membrane fusion protein (acrA, ARO: 1,000,001, ARO: 3,000,207) } \\
\text { OR (mdtA, ARO: 1,000,001, ARO: } 3,000,792 \text { ) }\end{array}$ & 56 \\
\hline RND multidrug efflux transporter; Acriflavin resistance protein & 2 \\
\hline Sensor histidine kinase PhoQ & 55 \\
\hline Sensory histidine kinase BaeS & 56 \\
\hline SSU rRNA (adenine (1518)-N (6)/adenine (1519)-N (6))-dimethyltransferase & 1 \\
\hline $\begin{array}{l}\text { Streptomycin 3"-O-adenylyltransferase @ Spectinomycin 9-O-adenylyltransferase } \\
\text { (spectinomycin, streptomycin) (ARO: 1,000,001, ARO: 3,000,232) } \\
\text { (tobramycin,gentamicin, dibekacin, sisomicin, kanamycin) }\end{array}$ & 9 \\
\hline Tetracycline efflux protein TetA & 55 \\
\hline Topoisomerase IV subunit A & 54 \\
\hline Transcription repressor of multidrug efflux pump acrAB operon, TetR (AcrR) family & 3 \\
\hline Transcriptional regulator of acrAB operon, AcrR & 56 \\
\hline Transcriptional regulatory protein PhoP & 55 \\
\hline Transcriptional repressor MprA & 55 \\
\hline Translation elongation factor Tu & 55 \\
\hline TrkA-N: Sodium/hydrogen exchanger & 3 \\
\hline Two-component system response regulator $\mathrm{OmpR}$ & 55 \\
\hline Type I secretion outer membrane protein, TolC precursor & 55 \\
\hline $\begin{array}{l}\text { UDP-4-amino-4-deoxy-L-arabinose formyltransferase/ UDP-glucuronic acid } \\
\text { oxidase (UDP-4-keto-hexauronic acid decarboxylating) }\end{array}$ & 1 \\
\hline
\end{tabular}

MdtBC that forms a drug transporter. In the absence of MdtB, the MdtAC-TolC has narrower drug specificity, leading to the loss of novobiocin resistance [98]. The MdtABC and AcrD systems may be related to bacterial metal homeostasis by transporting metals directly. This is to some extent similar to the copper and silver resistance mechanism by cation efflux of the CusABC system belonging to the RND protein superfamily [97, 99].

As stated before, this is the first report for spontaneous resistance against nanosilver. However, Gunawan et al., (2013) reported the natural ability of Bacillus sp. to adapt to nanosilver cytotoxicity under prolonged cellular oxidative stress stimulation through the nanoparticles incubation [14]. They found that the induced effects of adaptation continued even after discontinuation of nanosilver exposure. They also suggested that this characteristic ability of the ubiquitously-occurring Bacillus $s p$. may pose adversative consequences to the extensive use of nanosilver. Moreover, Graves et al., (2015) showed that after 225 generations of the treatment with nanosilver, the treated E. coli populations demonstrated greater fitness compared with control strains in the presence of silver nanoparticles [54]. We could also have suggested that the observed $P$. mirabilis SCDR1 nanosilver resistance might be an adaptive effect of the use of silver containing bandages in the Diabetic foot ulcer clinic. However, the reference strain P. mirabilis ATCC 29906 (isolated from urogenital tract of Homo sapiens) also showed resistance against colloidal nanosilver. In addition, it seems that nanosilver resistance is a widespread character in $P$. mirabilis species, since all other tested 50 isolates showed resistance against colloidal nanosilver [unpublished data]. Comparative metal resistance in $P$. mirabilis genomes contains some of the genetics determinants that can aid in nanosilver/silver resistance [unpublished data]. However, this conclusion needs to be further tested in a larger number of $P$. mirabilis isolated from different infection sites and geographical locations.

Increasing antimicrobial nanosilver usage could prompt a silver resistance problem in Gram-negative pathogens, particularly since silver resistance is already known to exist in several such species [81, 


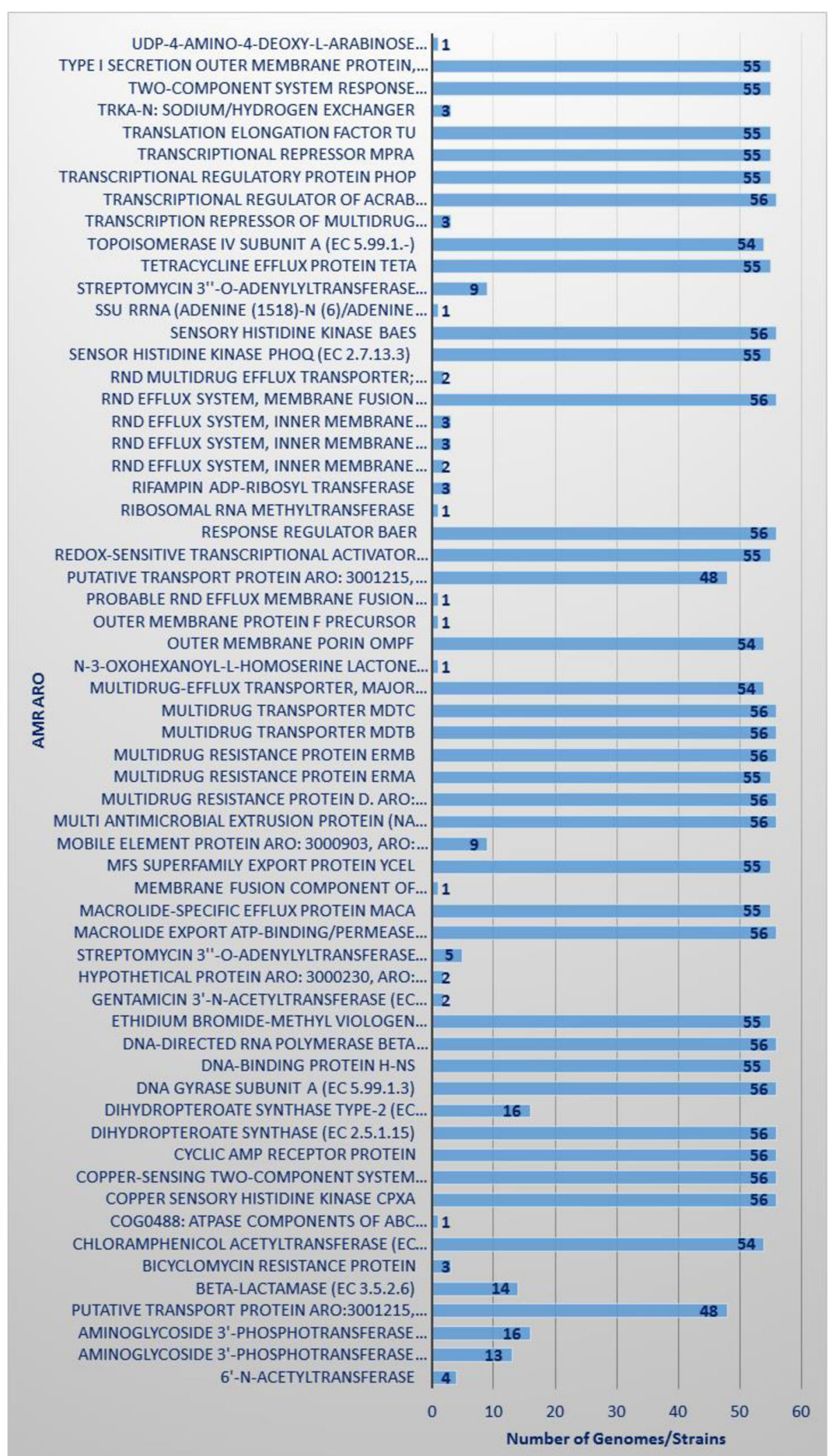

Fig. 8 Species wide Proteus mirabilis antibiotic resistome constituents 
Table 7 Consensus P. mirabilis-SCDR1 antibiotic Resistome

\begin{tabular}{|c|c|c|c|c|c|c|c|}
\hline Source & Source Organism & Gene & Product & Function & $\begin{array}{l}\text { Query } \\
\text { Coverage }\end{array}$ & Identity & E-value \\
\hline$\overline{A R D B}$ & $\begin{array}{l}\text { P. mirabilis ATCC } \\
29906\end{array}$ & tetAJ & $\begin{array}{l}\text { Tetracycline efflux } \\
\text { protein TetA }\end{array}$ & $\begin{array}{l}\text { Major facilitator superfamily } \\
\text { transporter, tetracycline efflux pump. }\end{array}$ & 97 & 95 & 0 \\
\hline CARD & P. mirabilis BB2000 & tetAJ & $\begin{array}{l}\text { Tetracycline efflux } \\
\text { protein TetA }\end{array}$ & $\begin{array}{l}\text { Major facilitator superfamily } \\
\text { transporter, tetracycline efflux pump. }\end{array}$ & 97 & 94 & 0 \\
\hline ARDB & P. mirabilis HI4320 & tetAJ & $\begin{array}{l}\text { Tetracycline efflux } \\
\text { protein TetA }\end{array}$ & $\begin{array}{l}\text { Major facilitator superfamily transporter, } \\
\text { tetracycline efflux pump. }\end{array}$ & 80 & 99 & $2 \mathrm{e}-74$ \\
\hline CARD & P. mirabilis BB2000 & gyrA & $\begin{array}{l}\text { DNA gyrase subunit A } \\
\text { (EC 5.99.1.3) }\end{array}$ & $\begin{array}{l}\text { Point mutation of Escherichia coli gyrA } \\
\text { resulted in the lowered affinity between } \\
\text { fluoroquinolones and gyrA. Thus, } \\
\text { conferring resistance }\end{array}$ & 98 & 99 & 0 \\
\hline CARD & P. mirabilis BB2000 & baeR & Response regulator BaeR & $\begin{array}{l}\text { BaeR is a response regulator that } \\
\text { promotes the expression of MdtABC } \\
\text { and AcrD efflux complexes. }\end{array}$ & 100 & 99 & $2 e-171$ \\
\hline CARD & P. mirabilis BB2000 & baes & Sensory histidine kinase BaeS & $\begin{array}{l}\text { BaeS is a sensor kinase in the BaeSR } \\
\text { regulatory system. While it phosphorylates } \\
\text { BaeR to increase its activity. }\end{array}$ & 100 & 99 & 0 \\
\hline CARD & P. mirabilis BB2000 & mdtC & Multidrug transporter MdtC & $\begin{array}{l}\text { MdtC is a transporter that forms a } \\
\text { hetero-multimer complex with MdtB to } \\
\text { form a multidrug transporter. MdtBC is } \\
\text { part of the MdtABC-TolC efflux complex. }\end{array}$ & 100 & 99 & 0 \\
\hline CARD & P. mirabilis BB2000 & mdtB & Multidrug transporter MdtB & $\begin{array}{l}\text { MdtB is a transporter that forms a } \\
\text { heteromultimer complex with MdtC to } \\
\text { form a multidrug transporter. MdtBC is } \\
\text { part of the MdtABC-TolC efflux complex. }\end{array}$ & 100 & 99 & 0 \\
\hline CARD & P. mirabilis BB2000 & mdtA & $\begin{array}{l}\text { RND efflux system, membrane } \\
\text { fusion protein }\end{array}$ & $\begin{array}{l}\text { MdtA is the membrane fusion protein } \\
\text { of the multidrug efflux complex mdtABC. }\end{array}$ & 100 & 98 & 0 \\
\hline CARD & P. mirabilis BB2000 & folP & $\begin{array}{l}\text { Dihydropteroate synthase } \\
\text { (EC 2.5.1.15) }\end{array}$ & $\begin{array}{l}\text { Point mutations in dihydropteroate } \\
\text { synthase folP prevent sulfonamide } \\
\text { antibiotics from inhibiting its role in } \\
\text { folate synthesis, thus conferring } \\
\text { sulfonamide resistance. }\end{array}$ & 100 & 100 & 0 \\
\hline CARD & P. mirabilis BB2000 & soxR & $\begin{array}{l}\text { Redox-sensitive transcriptional } \\
\text { activator SoxR }\end{array}$ & $\begin{array}{l}\text { SoxR is a sensory protein that upregulates } \\
\text { soxS expression in the presence of } \\
\text { redox-cycling drugs. This stress response } \\
\text { leads to the expression many multidrug } \\
\text { efflux pumps. }\end{array}$ & 100 & 100 & 0 \\
\hline CARD & $\begin{array}{l}\text { Shigella dysenteriae } \\
\text { Sd197 }\end{array}$ & ompR & $\begin{array}{l}\text { Two-component system } \\
\text { response regulator OmpR }\end{array}$ & Transcriptional regulatory protein & 99 & 87 & 0 \\
\hline CARD & P. mirabilis BB2000 & emrR & $\begin{array}{l}\text { Transcriptional repressor } \\
\text { MprA }\end{array}$ & $\begin{array}{l}\text { EmrR is a negative regulator for the } \\
\text { EmrAB-TolC multidrug efflux pump } \\
\text { in E. coli. Mutations lead to EmrAB- } \\
\text { TolC overexpression. }\end{array}$ & 100 & 100 & 0 \\
\hline CARD & P. mirabilis BB2000 & emrA & $\begin{array}{l}\text { Multidrug resistance } \\
\text { protein ErmA }\end{array}$ & $\begin{array}{l}\text { EmrA is a membrane fusion protein, } \\
\text { providing an efflux pathway with } \\
\text { EmrB and TolC between the inner } \\
\text { and outer membranes of E. coli, } \\
\text { a Gram-negative bacterium. }\end{array}$ & 95 & 96 & 0 \\
\hline CARD & P. mirabilis BB2000 & acrE & $\begin{array}{l}\text { Membrane fusion component } \\
\text { of tripartite multidrug } \\
\text { resistance system }\end{array}$ & $\begin{array}{l}\text { AcrEF-TolC is a tripartite multidrug } \\
\text { efflux system similar to AcrAB-TolC } \\
\text { and found in Gram-negative bacteria. } \\
\text { AcrE is the membrane fusion protein, } \\
\text { AcrF is the inner membrane transporter, } \\
\text { and TolC is the outer membrane channel } \\
\text { protein. }\end{array}$ & 100 & 98 & $3 e-44$ \\
\hline CARD & P. mirabilis BB2000 & emrB & $\begin{array}{l}\text { Multidrug resistance } \\
\text { protein ErmB }\end{array}$ & $\begin{array}{l}\text { emrB is a translocase in the emrB -TolC } \\
\text { efflux protein in E. coli. It recognizes } \\
\text { substrates including carbonyl cyanide } \\
\text { m-chlorophenylhydrazone (CCCP), } \\
\text { nalidixic acid, and thioloactomycin. }\end{array}$ & 100 & 99 & 0 \\
\hline CARD & P. mirabilis BB2000 & rров & $\begin{array}{l}\text { DNA-directed RNA polymerase } \\
\text { beta subunit (EC 2.7.7.6) }\end{array}$ & $\begin{array}{l}\text { Mutations in rpoB gene confers antibiotic } \\
\text { resistance (Daptomycin and Rifamycin) }\end{array}$ & 100 & 99 & 0 \\
\hline CARD & P. mirabilis BB2000 & tufB & $\begin{array}{l}\text { Translation elongation factor } \\
\text { Tu }\end{array}$ & $\begin{array}{l}\text { Sequence variants of elongation factor } \\
\text { Tu confer resistance to elfamycin antibiotics. }\end{array}$ & 100 & 100 & $1 e-43$ \\
\hline CARD & P. mirabilis BB2000 & cpxA & Copper sensory histidine & cpxA mutant confer resistant to amikacin & 94 & 99 & 0 \\
\hline
\end{tabular}


Table 7 Consensus P. mirabilis-SCDR1 antibiotic Resistome (Continued)

\begin{tabular}{|c|c|c|c|c|c|c|c|}
\hline Source & Source Organism & Gene & Product & Function & $\begin{array}{l}\text { Query } \\
\text { Coverage }\end{array}$ & Identity & E-value \\
\hline CARD & P. mirabilis $\mathrm{BB} 2000$ & $\operatorname{cpxR}$ & $\begin{array}{l}\text { Copper-sensing two-component } \\
\text { system response } \\
\text { regulator CpxR }\end{array}$ & $\begin{array}{l}\text { CpxR is a regulator that promotes acrD } \\
\text { expression when phosphorylated by a } \\
\text { cascade involving CpxA, a sensor kinase. } \\
\text { Cefepime and chloramphenicol }\end{array}$ & 100 & 100 & 0 \\
\hline CARD & P. mirabilis BB2000 & emrD & Multidrug resistance protein $\mathrm{D}$ & $\begin{array}{l}\text { EmrD is a multidrug transporter from } \\
\text { the Major Facilitator Superfamily (MFS) } \\
\text { primarily found in Escherichia coli. EmrD } \\
\text { couples efflux of amphipathic compounds } \\
\text { with proton import across the plasma } \\
\text { membrane. }\end{array}$ & 100 & 99 & 0 \\
\hline CARD & P. mirabilis BB2000 & macA & $\begin{array}{l}\text { Macrolide-specific efflux } \\
\text { protein MacA }\end{array}$ & $\begin{array}{l}\text { MacA is a membrane fusion protein that } \\
\text { forms an antibiotic efflux complex with } \\
\text { MacB and TolC. }\end{array}$ & 100 & 99 & $3 e-177$ \\
\hline CARD & P. mirabilis BB2000 & $\operatorname{macB}$ & $\begin{array}{l}\text { Macrolide export ATP-binding } \\
\text { /permease protein MacB } \\
\text { (EC 3.6.3.-) }\end{array}$ & $\begin{array}{l}\text { MacB is an ATP-binding cassette (ABC) } \\
\text { transporter that exports macrolides with } \\
\text { 14- or } 15-\text { membered lactones. It forms } \\
\text { an antibiotic efflux complex with } \\
\text { MacA and TolC. }\end{array}$ & 100 & 98 & 0 \\
\hline ARDB & P. mirabilis ATCC 29906 & cat & $\begin{array}{l}\text { Chloramphenicol acetyltransferase } \\
\text { (EC 2.3.1.28) }\end{array}$ & $\begin{array}{l}\text { Group A chloramphenicol acetyltransferase, } \\
\text { which can inactivate chloramphenicol. }\end{array}$ & 99 & 93 & $6 e-150$ \\
\hline CARD & P. mirabilis BB2000 & cat & $\begin{array}{l}\text { Chloramphenicol acetyltransferase } \\
\text { (EC 2.3.1.28) }\end{array}$ & $\begin{array}{l}\text { Group A chloramphenicol acetyltransferase, } \\
\text { which can inactivate chloramphenicol. }\end{array}$ & 99 & 93 & $4 e-151$ \\
\hline CARD & P. mirabilis BB2000 & $\mathrm{acrR}$ & $\begin{array}{l}\text { Transcription repressor of multidrug } \\
\text { efflux pump acrAB operon, } \\
\text { TetR (AcrR) family }\end{array}$ & $\begin{array}{l}\text { AcrR is a repressor of the AcrAB-TolC } \\
\text { multidrug efflux complex. AcrR mutations } \\
\text { result in high level antibiotic resistance. }\end{array}$ & 100 & 95 & $9 e-25$ \\
\hline CARD & P. mirabilis BB2000 & $\mathrm{acrR}$ & $\begin{array}{l}\text { Transcriptional regulator of acrAB } \\
\text { operon, AcrR }\end{array}$ & $\begin{array}{l}\text { AcrR is a repressor of the AcrAB-TolC } \\
\text { multidrug efflux complex. AcrR mutations } \\
\text { result in high level antibiotic resistance. }\end{array}$ & 93 & 95 & $2 e-114$ \\
\hline CARD & P. mirabilis BB2000 & acrA & $\begin{array}{l}\text { RND efflux system, membrane } \\
\text { fusion protein }\end{array}$ & $\begin{array}{l}\text { Protein subunit of AcrA-AcrB-TolC } \\
\text { multidrug efflux complex. AcrA represents } \\
\text { the periplasmic portion of the transport protein. }\end{array}$ & 100 & 99 & 0 \\
\hline CARD & P. mirabilis BB2000 & mdtK & $\begin{array}{l}\text { Multi antimicrobial extrusion } \\
\text { protein }(\mathrm{Na}(+) / \text { drug antiporter), } \\
\text { MATE family of MDR efflux } \\
\text { pumps }\end{array}$ & $\begin{array}{l}\text { A multidrug and toxic compound extrusions } \\
\text { (MATE) transporter conferring resistance } \\
\text { to norfloxacin, doxorubicin and acriflavine. }\end{array}$ & 98 & 99 & $3 e-164$ \\
\hline CARD & $\begin{array}{l}\text { Salmonella enterica subsp. enterica } \\
\text { serovar Agona str. SL483 }\end{array}$ & hns & DNA-binding protein H-NS & $\begin{array}{l}\text { H-NS is a histone-like protein involved in } \\
\text { global gene regulation in Gram-negative } \\
\text { bacteria. It is a repressor of the membrane } \\
\text { fusion protein genes acrE, mdtE, and emrk } \\
\text { as well as nearby genes of many RND-type } \\
\text { multidrug exporters. }\end{array}$ & 100 & 80 & 0 \\
\hline CARD & P. mirabilis BB2000 & tufB & $\begin{array}{l}\text { Translation elongation factor } \\
\text { Tu }\end{array}$ & $\begin{array}{l}\text { Sequence variants of elongation factor } \\
\text { Tu confer resistance to elfamycin antibiotics. }\end{array}$ & 100 & 99 & 0 \\
\hline CARD & $\begin{array}{l}\text { Shigella dysenteriae } \\
\text { Sd197 }\end{array}$ & crp & Cyclic AMP receptor protein & $\begin{array}{l}\text { CRP is a global regulator that represses } \\
\text { MdtEF multidrug efflux pump expression. }\end{array}$ & 100 & 98 & 0 \\
\hline CARD & P. mirabilis $\mathrm{BB} 2000$ & emrE & $\begin{array}{l}\text { Ethidium bromide-methyl } \\
\text { viologen resistance protein } \\
\text { EmrE }\end{array}$ & $\begin{array}{l}\text { EmrE is a small multidrug transporter that } \\
\text { functions as a homodimer and that couples } \\
\text { the efflux of small polyaromatic cations from } \\
\text { the cell with the import of protons down } \\
\text { an electrochemical gradient. EmrE is found } \\
\text { in E. coli and P. aeruginosa. }\end{array}$ & 100 & 99 & $6 e-73$ \\
\hline CARD & P. mirabilis BB2000 & mdtK & $\begin{array}{l}\text { Multi antimicrobial extrusion protein } \\
(\mathrm{Na}(+) / \text { drug antiporter), MATE family } \\
\text { of MDR efflux pumps }\end{array}$ & $\begin{array}{l}\text { A multidrug and toxic compound extrusions } \\
\text { (MATE) transporter conferring resistance } \\
\text { to norfloxacin, doxorubicin and acriflavine. }\end{array}$ & 100 & 100 & $2 \mathrm{e}-113$ \\
\hline CARD & P. mirabilis $\mathrm{BB} 2000$ & NIA & Putative transport protein & NIA & 100 & 94 & $7 e-59$ \\
\hline CARD & P. mirabilis $\mathrm{BB} 2000$ & NIA & Multidrug resistance protein & NIA & 99 & 96 & $2 \mathrm{e}-112$ \\
\hline CARD & P. mirabilis BB2000 & parC & $\begin{array}{l}\text { Topoisomerase I subunit } \\
\text { A (EC 5.99.1.-) }\end{array}$ & $\begin{array}{l}\text { ParC is a subunit of topoisomerase IV, } \\
\text { which decatenates and relaxes DNA to } \\
\text { allow access to genes for transcription or } \\
\text { translation. Point mutations in ParC prevent } \\
\text { fluoroquinolone antibiotics from inhibiting } \\
\text { DNA synthesis, and confer low-level resistance. } \\
\text { Higher-level resistance results from both gyrA } \\
\text { and parC mutations. }\end{array}$ & 99 & 99 & 0 \\
\hline
\end{tabular}


Table 7 Consensus P. mirabilis-SCDR1 antibiotic Resistome (Continued)

\begin{tabular}{|c|c|c|c|c|c|c|c|}
\hline Source & Source Organism & Gene & Product & Function & $\begin{array}{l}\text { Query } \\
\text { Coverage }\end{array}$ & Identity & E-value \\
\hline CARD & P. mirabilis BB2000 & parE & $\begin{array}{l}\text { Topoisomerase IV subunit } \\
\text { B (EC 5.99.1.-) }\end{array}$ & $\begin{array}{l}\text { ParE is a subunit of topoisomerase IV, } \\
\text { necessary for cell survival. Point mutations } \\
\text { in ParE prevent fluoroquinolones from } \\
\text { inhibiting DNA synthesis, thus conferring } \\
\text { resistance. }\end{array}$ & 100 & 99 & 0 \\
\hline CARD & P. mirabilis BB2000 & tolC & $\begin{array}{l}\text { Type I secretion outer } \\
\text { membrane protein, } \\
\text { TolC precursor }\end{array}$ & $\begin{array}{l}\text { TolC is a protein subunit of many multidrug } \\
\text { efflux complexes in Gram negative bacteria. } \\
\text { It is an outer membrane efflux protein and } \\
\text { is constitutively open. Regulation of efflux } \\
\text { activity is often at its periplasmic entrance } \\
\text { by other components of the efflux complex. }\end{array}$ & 100 & 99 & 0 \\
\hline CARD & P. mirabilis BB2000 & $\mathrm{mdtH}$ & $\begin{array}{l}\text { MFS superfamily } \\
\text { export protein YceL }\end{array}$ & Multidrug resistance protein $\mathrm{MdtH}$ & 100 & 99 & 0 \\
\hline CARD & P. mirabilis BB2000 & phoP & $\begin{array}{l}\text { Transcriptional } \\
\text { regulatory protein } \\
\text { PhoP }\end{array}$ & $\begin{array}{l}\text { A mutant phoP activates pmrHFIJKLM } \\
\text { expression responsible for L-aminoarabinose } \\
\text { synthesis and polymyxin resistance, by way } \\
\text { of alteration of negative charge }\end{array}$ & 100 & 99 & $5 e-165$ \\
\hline CARD & P. mirabilis BB2000 & phoQ & $\begin{array}{l}\text { Sensor histidine kinase } \\
\text { PhoQ (EC 2.7.13.3) }\end{array}$ & $\begin{array}{l}\text { Mutations in Pseudomonas aeruginosa } \\
\mathrm{PhoQ} \text { of the two-component PhoPQ } \\
\text { regulatory system. Presence of mutation } \\
\text { confers resistance to colistin }\end{array}$ & 90 & 99 & 0 \\
\hline CARD & P. mirabilis BB2000 & phoQ & $\begin{array}{l}\text { Sensor histidine kinase } \\
\text { PhoQ (EC 2.7.13.3) }\end{array}$ & $\begin{array}{l}\text { Mutations in Pseudomonas aeruginosa } \\
\mathrm{PhoQ} \text { of the two-component PhoPQ } \\
\text { regulatory system. Presence of mutation } \\
\text { confers resistance to colistin }\end{array}$ & 98 & 98 & $1 e-45$ \\
\hline \multicolumn{8}{|c|}{$\begin{array}{l}\text { Evidence: BLASTP, NIA: No information available, ARDB: Antibiotic Resistance Genes Database, CARD: Comprehensive Antibiotic Resistance Database } \\
\text { - MdtC: In the absence of MdtB, MdtC can form a homomultimer complex that results in a functioning efflux complex with a narrower drug specificity } \\
\text { - MdtABC-TolC https://card.mcmaster.ca/ontology/37167 } \\
\text { - Elongation factor Tu is required for peptide elongation in bacterial protein synthesis } \\
\text { - cpxA http://www.uniprot.org/citations/2185221 } \\
\text { - cpxR Srinivasan VB, et al. 2012. PLoS One 7(4): E33777. Role of the two component signal transduction system CpxAR in conferring cefepime and chloramphenicol } \\
\text { resistance in Klebsiella pneumoniae NTUH-K2044. (PMID 22496764) }\end{array}$} \\
\hline
\end{tabular}

100]. Both exogenous (horizontally acquired Sil system) endogenous (mutational Cus system) resistance to silver has been reported in Gram-negative bacteria [13, 81]. Li et al. [81] selected five Escherichia coli mutants that present $a \geq 64$-fold decreases in silver susceptibility compared with their original strain. All the mutants exhibited loss of expression of outer membrane porins $(\mathrm{OmpF}$ or $\mathrm{OmpF} / \mathrm{C})$, which seemingly resulted in the reduction of outer membrane permeability. These findings implied that reduced silver susceptibility is a result of restricting silver entrance into the bacterial cell. Moreover, they found that these mutants express active efflux that pumps silver outside of the cell. It was found that the cus CFBA operon is the responsible of silver efflux pump. Similarly, in our case, we observed the presence of resistance operon with high similarity to the cus operon, which is a chromosomally encoded system because of the lack of any plasmid in P. mirabilis SCDR1. However, both endogenous and exogenous silver resistance systems, in Gram-negative bacteria, remain incompletely understood [83].

The occurrence of induced nanosilver resistance (in vitro) in Bacillus sp. and E. coli [14, 54], spontaneous resistance (in our case) and the frequent uses and misuses of nanosilver-containing medical products should suggest adopting an enhanced surveillance systems for nanosilver-resistant isolates in medical setups. In addition, there should be greater control over utilizing nanosilver-containing products in order to maintain nanosilver as a valuable alternative approach in the fight against multidrug resistant pathogens.

\section{Conclusion}

In the present study, we introduced the $P$. mirabilis SCDR1 isolate that was collected from a diabetic ulcer patient. P. mirabilis SCDR1 showed high levels of resistance against nanosilver colloids, nanosilver chitosan composite and the commercially available nanosilver and silver bandages. Our isolate contains all the required pathogenicity and virulence factors to establish a successful infection. P. mirabilis SCDR1 contains several physical and biochemical mechanisms for antibiotics and silver/nanosilver resistance, which are biofilm formation, swarming mobility, efflux systems, and enzymatic detoxification. 
Table 8 P. mirabilis SCDR1 Heavy Metal Resistance/Binding factors

\begin{tabular}{|c|c|c|c|c|c|c|}
\hline Annotation & Reference Genome & Accession Number & Gene & Protein ID & $\begin{array}{l}\text { AA } \\
\text { Length }\end{array}$ & Corresponding Protein \\
\hline PATRIC & P. mirabilis ATCC 29906 & NZ_GG668580 & $\operatorname{corC}$ & ZP_03842837.1 & 293 & Magnesium/cobalt efflux protein CorC. \\
\hline RefSeq & P. mirabilis BB2000 & CP004022 & NA & AGS60530.1 & 305 & $\begin{array}{l}\text { cation efflux protein (Divalent metal cation } \\
\text { (Fe/Co/Zn/Cd) transporter). }\end{array}$ \\
\hline PATRIC & P. mirabilis ATCC 29906 & NZ_GG668576 & cueR & ZP_03840921.1 & 133 & $\begin{array}{l}\text { MerR-family transcriptional regulator } \\
\text { (copper efflux regulator). }\end{array}$ \\
\hline RefSeq & P. mirabilis BB2000 & CP004022 & $\operatorname{ars} B$ & AGS60689.1 & 429 & $\begin{array}{l}\text { Arsenical pump membrane protein } \\
\text { (ArsB_permease). }\end{array}$ \\
\hline RefSeq & P. mirabilis BB2000 & CP004022 & NA & $\begin{array}{l}\text { AGS59089.1 } \\
\text { AGS59090.1 } \\
\text { AGS59091.1 }\end{array}$ & $\begin{array}{l}129 \\
678 \\
243\end{array}$ & Metal resistance protein. \\
\hline PATRIC & $\begin{array}{l}\text { P. mirabilis ATCC } 29906 \\
\text { P. mirabilis strain } 25,933 \text { GTA }\end{array}$ & $\begin{array}{l}\text { NZ_GG668576 } \\
\text { LANL01000027 }\end{array}$ & $\begin{array}{l}\text { ahpF } \\
\text { NA }\end{array}$ & $\begin{array}{l}\text { ZP_03839875.1 } \\
\text { KKC60389.1 }\end{array}$ & $\begin{array}{l}521 \\
678\end{array}$ & Protein-disulfide reductase. \\
\hline PATRIC & P. mirabilis ATCC 29906 & $\begin{array}{l}\text { NZ_GG668576 } \\
\text { NZ_GG668583 }\end{array}$ & $\begin{array}{l}\text { dsbB } \\
\text { dsbA }\end{array}$ & $\begin{array}{l}\text { ZP_03840198.1 } \\
\text { ZP_03839563.1 }\end{array}$ & $\begin{array}{l}174 \\
207\end{array}$ & Protein disulfide oxidoreductase. \\
\hline PATRIC & $\begin{array}{l}\text { P. mirabilis ATCC } 29906 \\
\text { P. mirabilis BB2000 }\end{array}$ & $\begin{array}{l}\text { NZ_GG668576 } \\
\text { NZ_GG668576 } \\
\text { NZ_GG668578 } \\
\text { CP004022 }\end{array}$ & $\begin{array}{l}\text { actP1 } \\
\text { copA } \\
\text { ppaA } \\
\text { zntA }\end{array}$ & $\begin{array}{l}\text { ZP_03840801.1 } \\
\text { ZP_03840922.1 } \\
\text { ZP_03842696.1 } \\
\text { AGS58561.1 }\end{array}$ & $\begin{array}{l}829 \\
984 \\
803 \\
796\end{array}$ & $\begin{array}{l}\text { (zinc/cadmium/mercury/lead- } \\
\text { transporting ATPase) (HMA). }\end{array}$ \\
\hline PATRIC & P. mirabilis ATCC 29906 & NZ_GG668578 & gloB & ZP_03842342.1 & 251 & hydroxyacylglutathione hydrolase. \\
\hline RefSeq & P. mirabilis strain ATCC 7002 & JOVJ01000008 & grxA & KGA90223.1 & 87 & Glutaredoxin, GrxA family. \\
\hline PATRIC & $\begin{array}{l}\text { P. mirabilis ATCC } 29906 \\
\text { P. mirabilis strain 1134_PMIR }\end{array}$ & $\begin{array}{l}\text { NZ_GG668576 } \\
\text { NZ_GG668576 }\end{array}$ & $\begin{array}{l}\text { gst1 } \\
\text { gst } \\
\text { Delta } \\
\text { Uncharacterized }\end{array}$ & $\begin{array}{l}\text { ZP_03840532.1 } \\
\text { ZP_03840063.1 } \\
\text { PGF_02913068 } \\
\text { PGF_00008413 }\end{array}$ & $\begin{array}{l}204 \\
203 \\
195 \\
110\end{array}$ & Glutathione S-transferase (EC 2.5.1.18). \\
\hline RefSeq & P. mirabilis BB2000 & CP004022 & cueO & AGS58840.1 & 526 & Multicopper oxidase. \\
\hline PATRIC & P. mirabilis ATCC 29906 & NZ_GG668578 & NA & ZP_03842149.1 & 243 & $\begin{array}{l}\text { FIG00003370: Multicopper } \\
\text { polyphenol oxidase. }\end{array}$ \\
\hline PATRIC & P. mirabilis strain ATCC 7002 & JOVJ01000009 & yobA & ZP_03839688.1 & 130 & $\begin{array}{l}\text { Copper resistance protein } \\
\text { (Copper-binding protein CopC } \\
\text { (methionine-rich)) [Inorganic ion } \\
\text { transport and metabolism]. }\end{array}$ \\
\hline PATRIC & P. mirabilis ATCC 29906 & NZ_GG668576 & copD & ZP_03839689.1 & 279 & Copper resistance protein. \\
\hline PATRIC & P. mirabilis strain SAS71 & LDIU01000481 & NA & PGF_00419563 & 114 & Copper resistance protein D. \\
\hline $\mathrm{BRC1}$ & P. mirabilis $\mathrm{HI} 4320$ & NC_010554 & NA & NA & 300 & $\begin{array}{l}\text { Putative copper resistance protein, } \\
\text { secreted. }\end{array}$ \\
\hline $\begin{array}{l}\text { PATRIC } \\
\text { RefSeq }\end{array}$ & P. mirabilis ATCC 29906 & NZ_GG668576 & copC & ZP_03839688.1 & 130 & Copper resistance protein CopC. \\
\hline PATRIC & E. coli 7-233-03_S4_C2 & JORW01000046 & copB & KEN13242.1 & 296 & Copper resistance protein B. \\
\hline PATRIC & P. mirabilis ATCC 29906 & NZ_GG668576 & cutC & ZP_03839779.1 & 250 & $\begin{array}{l}\text { Copper homeostasis protein CutC } \\
\text { (Cytoplasmic copper homeostasis } \\
\text { protein CutC). }\end{array}$ \\
\hline RefSeq & P. mirabilis BB2000 & CP004022 & $\operatorname{cop} A$ & AGS60771.1 & 904 & Copper exporting ATPase. \\
\hline PATRIC & P. mirabilis ATCC 29906 & NZ_GG668576 & $\operatorname{cop} A$ & ZP_03840922.1 & 949 & $\begin{array}{l}\text { Lead, cadmium, zinc and mercury } \\
\text { transporting ATPase (EC 3.6.3.3) } \\
\text { (EC 3.6.3.5); Copper-translocating } \\
\text { P-type ATPase (EC 3.6.3.4). }\end{array}$ \\
\hline RefSeq & $\begin{array}{l}\text { P. mirabilis strain } \\
\text { ATCC } 7002\end{array}$ & JOVJ01000009 & $\mathrm{kdpB}$ & KGA89427.1 & 685 & $\begin{array}{l}\text { Copper exporting ATPase } \\
\text { (potassium-transporting ATPase subunit B). }\end{array}$ \\
\hline RefSeq & P. mirabilis & $\begin{array}{l}\text { WP_012368272.1, } \\
\text { WP_020946123.1 }\end{array}$ & copA-CopZ-HMA & $\begin{array}{l}\text { WP_012368272 } \\
\text { WP_020946123 }\end{array}$ & 984 & $\begin{array}{l}\text { Copper exporting ATPase } \\
\text { (Heavy-metal-associated domain (HMA)). }\end{array}$ \\
\hline RefSeq & $\begin{array}{l}\text { P. mirabilis strain } \\
\text { ATCC } 7002\end{array}$ & JOVJ01000005 & cueR & KGA91278.1 & 135 & $\begin{array}{l}\text { Copper -responsive transcriptional } \\
\text { regulator (HTH_MerR-SF Superfamily). }\end{array}$ \\
\hline PATRIC & $\begin{array}{l}\text { P. mirabilis BB2000 } \\
\text { P. mirabilis strain } \\
\text { 1310_PMIR }\end{array}$ & $\begin{array}{l}\text { CP004022 } \\
\text { JVUH01000152 } \\
\text { JVUH01001396 }\end{array}$ & cutF & $\begin{array}{l}\text { ZP_03841587.1 } \\
\text { PGF_00241126 } \\
\text { PGF_00241126 }\end{array}$ & $\begin{array}{l}225 \\
154 \\
78\end{array}$ & $\begin{array}{l}\text { Copper homeostasis protein CutF } \\
\text { precursor/Lipoprotein NIpE involeved } \\
\text { in surface adhesion. }\end{array}$ \\
\hline
\end{tabular}


Table 8 P. mirabilis SCDR1 Heavy Metal Resistance/Binding factors (Continued)

\begin{tabular}{|c|c|c|c|c|c|c|}
\hline Annotation & Reference Genome & Accession Number & Gene & Protein ID & $\begin{array}{l}\text { AA } \\
\text { Length }\end{array}$ & Corresponding Protein \\
\hline $\begin{array}{l}\text { PATRIC } \\
\text { RefSeq }\end{array}$ & P. mirabilis BB2000 & CP004022 & $\begin{array}{l}\text { terB } \\
\text { terA } \\
\text { terC } \\
\text { terD } \\
\text { terE } \\
\text { terZ }\end{array}$ & $\begin{array}{l}\text { AGS60978.1 } \\
\text { AGS60979.1 } \\
\text { AGS60977.1 } \\
\text { AGS60976.1 } \\
\text { AGS60975.1 } \\
\text { AGS60980.1 }\end{array}$ & $\begin{array}{l}151 \\
382 \\
341 \\
192 \\
191 \\
194\end{array}$ & P. mirabilis tellurite resistance loci. \\
\hline $\begin{array}{l}\text { PATRIC } \\
\text { RefSeq }\end{array}$ & Mycobacterium sp. & $\begin{array}{l}\text { YP_001705575.1 } \\
\text { CP002992 }\end{array}$ & $\operatorname{ctpC}$ & AEN01737.1 & 718 & $\begin{array}{l}\text { Probable cation-transporting ATPase G } \\
\text { (ATPase-IB2_Cd). }\end{array}$ \\
\hline PATRIC & P. mirabilis ATCC 29906 & NZ_GG668579 & $y n+B$ & ZP_03841770.1 & 325 & $\begin{array}{l}\text { Nickel transport system permease protein } \\
\text { nikB2 (TC 3.A.1.5.3). }\end{array}$ \\
\hline PATRIC & P. mirabilis ATCC 29906 & NZ_GG668579 & yntA & ZP_03841771.1 & 527 & $\begin{array}{l}\text { Nickel ABC transporter, periplasmic } \\
\text { nickel-binding protein nikA2 (TC 3.A.1.5.3). }\end{array}$ \\
\hline PATRIC & P. mirabilis ATCC 29906 & NZ_GG668583 & NA & ZP_03839446.1 & 289 & $\begin{array}{l}\text { Nickel transport system permease protein } \\
\text { NikC (TC 3.A.1.5.3). }\end{array}$ \\
\hline PATRIC & P. mirabilis ATCC 29906 & NZ_GG668583 & NA & ZP_03839447.1 & 269 & $\begin{array}{l}\text { Nickel transport ATP-binding protein } \\
\text { NikD (TC 3.A.1.5.3). }\end{array}$ \\
\hline PATRIC & P. mirabilis ATCC 29906 & NZ_GG668579 & $y n t D$ & ZP_03841768.1 & 267 & $\begin{array}{l}\text { Nickel transport ATP-binding protein } \\
\text { nikD2 (TC 3.A.1.5.3). }\end{array}$ \\
\hline PATRIC & P. mirabilis ATCC 29906 & NZ_GG668579 & yntE & ZP_03841767.1 & 203 & $\begin{array}{l}\text { Nickel transport ATP-binding protein } \\
\text { nikE2 (TC 3.A.1.5.3). }\end{array}$ \\
\hline PATRIC & P. mirabilis ATCC 29906 & NZ_GG668579 & yntC & ZP_03841769.1 & 270 & $\begin{array}{l}\text { Nickel transport system permease } \\
\text { protein nikC2 (TC 3.A.1.5.3). }\end{array}$ \\
\hline PATRIC & P. mirabilis BB2000 & CP004022 & hybF & AGS58541.1 & 113 & $\begin{array}{l}\text { [NiFe] hydrogenase nickel incorporation } \\
\text { protein HypA. }\end{array}$ \\
\hline PATRIC & P. mirabilis ATCC 29906 & NZ_GG668578 & hybB & ZP_03842517.1 & 282 & $\begin{array}{l}\text { [NiFe] hydrogenase nickel } \\
\text { incorporation-associated protein HypB. }\end{array}$ \\
\hline RefSeq & C. crescentus OR37 & APMP01000019 & NA & ENZ81282.1 & 723 & $\begin{array}{l}\text { Copper/silver/heavy metal-translocating } \\
\text { P-type ATPase, } \mathrm{Cd} / \mathrm{Co} / \mathrm{Hg} / \mathrm{Pb} / \mathrm{Zn} \text {-transporting. }\end{array}$ \\
\hline RefSeq & $\begin{array}{l}\text { Armatimonadetes bacterium } \\
\text { OLB18 } \\
\text { C. gilvus }\end{array}$ & $\begin{array}{l}\text { JZQX01000123 } \\
\text { WP_013884717.1 }\end{array}$ & $\operatorname{arsM}$ & KXK16912.1 & 283 & $\begin{array}{l}\text { Arsenite S-adenosylmethyltransferase } \\
\text { (Methyltransferase type 11). }\end{array}$ \\
\hline RefSeq & R. palustris TIE-1 & NC_011004 & NA & YP_001990857.1 & 973 & $\begin{array}{l}\text { Heavy metal translocating P-type ATPase } \\
\text { (ATPase-IB1_Cu). }\end{array}$ \\
\hline RefSeq & M. ulcerans str. Harvey & EUA92940.1, & CuRO_2_CopA_like1 & EUA92940.1 & 552 & Multicopper oxidase family protein. \\
\hline RefSeq & B. mallei NCTC 10229 & NC_008835 & oprB & YP_001024205.1 & 553 & $\begin{array}{l}\text { Copper/silver efflux system outer membrane } \\
\text { protein CusC (outer membrane efflux } \\
\text { protein OprB). }\end{array}$ \\
\hline RefSeq & B. pseudomallei 576 & NZ_ACCE01000001 & oprM & ZP_03450560.1 & 558 & $\begin{array}{l}\text { Copper/silver efflux system outer membrane } \\
\text { protein CusC (outer membrane efflux } \\
\text { protein OprM). }\end{array}$ \\
\hline $\begin{array}{l}\text { PATRIC } \\
\text { RefSeq }\end{array}$ & $\begin{array}{l}\text { Achromobacter } s p \text {. strain } \\
\text { 2789STDY5608636 } \\
\text { B. pseudomallei } 1710 \mathrm{~b}\end{array}$ & $\begin{array}{l}\text { CYTV01000008 } \\
\text { ABA52627.1 }\end{array}$ & cusC_1 & ABA52627 & 515 & $\begin{array}{l}\text { Copper/silver efflux system outer membrane } \\
\text { protein CusC (RND efflux system outer } \\
\text { membrane lipoprotein). }\end{array}$ \\
\hline RefSeq & $\begin{array}{l}\text { Achromobacter } s p \text {. strain } \\
\text { 2789STDY5608623 }\end{array}$ & CYSZ01000001 & NA & CUI29018.1 & 98 & $\begin{array}{l}\text { Outer membrane component of tripartite } \\
\text { multidrug resistance system (CusC). }\end{array}$ \\
\hline RefSeq & R. opacus & $\begin{array}{l}\text { WP_012687282.1, } \\
\text { BAH48260.1 }\end{array}$ & merB & WP_012687282 & 334 & Alkylmercury lyase (MerB). \\
\hline $\begin{array}{l}\text { PATRIC } \\
\text { RefSeq }\end{array}$ & $\begin{array}{l}\text { B. ubonensis strain } \\
\text { MSMB2185WGS }\end{array}$ & $\begin{array}{l}\text { Q44585.1 } \\
\text { LPIU01000068 }\end{array}$ & NA & $\begin{array}{l}\text { Q44585 } \\
\text { PGF_01102114 }\end{array}$ & $\begin{array}{l}379 \\
377\end{array}$ & Nickel-cobalt-cadmium resistance protein NccB. \\
\hline PATRIC & P. mirabilis BB2000 & CP004022 & zntA & AGS58561.1 & 798 & $\begin{array}{l}\text { Lead, cadmium, zinc and mercury transporting } \\
\text { ATPase (EC 3.6.3.3) (EC 3.6.3.5); } \\
\text { Copper-translocating P-type ATPase (EC 3.6.3.4) }\end{array}$ \\
\hline PATRIC & P. mirabilis BB2000 & СР004022 & copA & AGS60771.1 & 949 & $\begin{array}{l}\text { Lead, cadmium, zinc and mercury transporting } \\
\text { ATPase (EC 3.6.3.3) (EC 3.6.3.5); } \\
\text { Copper-translocating P-type ATPase (EC 3.6.3.4). }\end{array}$ \\
\hline PATRIC & P. mirabilis BB2000 & СР004022 & copA & AGS60770.1 & 54 & $\begin{array}{l}\text { Lead, cadmium, zinc and mercury transporting } \\
\text { ATPase (EC 3.6.3.3) (EC 3.6.3.5); } \\
\text { Copper-translocating P-type ATPase (EC 3.6.3.4). }\end{array}$ \\
\hline
\end{tabular}




\section{Additional files}

Additional file 1: Table S1. Distribution of unique gene counts amongst different metabolic pathways. (DOCX $11 \mathrm{~kb}$ )

Additional file 2: Table S2. Distribution of unique gene counts amongst pathways Classes and subclasses. (DOCX 16 kb)

Additional file 3: Table S3. P. mirabilis SCDR1 Pathogen Finder results. (DOCX $25 \mathrm{~kb}$ )

Additional file 4: Table S4. Major pathogenic virulence factors for Proteus mirabilis SCDR1. (DOCX $32 \mathrm{~kb}$ )

Additional file 5: Table S5. Strict Antibiotic resistance analysis of Proteus mirabilis SCDR1. (DOCX $17 \mathrm{~kb}$ )

Additional file 6: Table S6. Modified loose Antibiotic resistance analysis of Proteus mirabilis SCDR1. (DOCX $65 \mathrm{~kb}$ )

Additional file 7: Table S7. Drug Resistance related protiens and its corresponding genes or proteins GenBank access numbers. (DOCX 16 kb)

\section{Abbreviations}

$16 S$ rRNA: 165 ribosomal RNA gene; AMRO: Antimicrobial Resistance based ontology; AROs: Antibiotic Resistance Ontology; BLASTn: Basic Local Alignment Search Tool nucleotide; bp: Base pair; DDT: 1, 1, 1-Trichloro-2, 2-bis (4-chlorophenyl) ethane; DFU: Diabeticfoot ulcer; GC content: guanine-cytosine content; KFSHRC: King Faisal Specialist Hospital and Research Center; Mb: Mega base pairs; MDR: multidrug-resistant; MIC: Minimum Inhibitory Concentration; MRSA: methicillin-resistant Staphylococcus aureus; MRSE: methicillin -resistant Staphylococcus epidermidis; NGS: Next generation sequencing techniques; PATRIC: Pathosystems recourse Integration center; PPM: part per million; RGI: Resistance Gene Identifier; RND: Resistance-Nodulation- Division; SCDR: Strategic center for Diabetes research; tRNAs: Transfer ribonucleic acid; VRE: Vancomycin-resistant Enterococcus

\section{Acknowledgements}

The authors want to thank the members of the Diabeticfoot unit in the University Diabetes Center at King Saud University for their help in collecting the bacteria samples. Furthermore, we want to thanks the members of the nanotechnology department in SCDR for providing the chitosan nanosilver composites. In addition we want to acknowledge that NGS experiments and analysis were supported by the Saudi Human Genome Program (SHGP) at KACST and KFSHRC. Moreover, we want to thank Dr. Rebecca Wattam, form the Biocomplexity Institute at Virginia Polytechnic Institute and State University, for her great assistance during data analysis using PATRIC services and tools.

\section{Funding}

The authors received internal research fund from King Faisal specialist hospital and research center to support the publication.

\section{Availability of data and materials}

Data from our draft genome of P. mirabilis SCDR1 isolate was deposited in NCBI-GenBank with an accession number LUFT00000000.

\section{Authors' contributions}

ATMS: Involved in study conception and design, data analysis and interpretation. Involved in drafting the manuscript or revising it critically for important intellectual content. Preparing the final approval of the version to be published. KA: Involved in study conception and design. Preparing the final approval of the version to be published. MAH: Involved in study design. Involved in acquisition of data, or analysis and interpretation of data; preparation and involved in drafting the manuscript. MS: Involved in acquisition of data, or analysis and interpretation of data. HT: Involved in study conception and design. Involved in drafting the manuscript or revising it critically for important intellectual content. Preparing the final approval of the version to be published. All authors read and approved the final manuscript.

\section{Ethics approval and consent to participate}

This study was approved by institutional review board in King Saud University, Collage of Medicine Riyadh, Kingdom of Saudi Arabia. The subject was provided written informed consent for participating in this study.
Consent for publication

All authors have consented for publication of this manuscript.

\section{Competing interests}

The authors declare that they have no competing interests

\section{Publisher's Note}

Springer Nature remains neutral with regard to jurisdictional claims in published maps and institutional affiliations.

\section{Author details}

${ }^{1}$ Genetics and Biotechnology Department, Strategic Center for Diabetes Research, College of medicine, King Saud University, Riyadh, Kingdom of Saudi Arabia. ${ }^{2}$ Genetics Department, King Faisal Specialist Hospital and Research Center, Riyadh, Kingdom of Saudi Arabia. ${ }^{3}$ Saudi Human Genome Project, King Abdulaziz City for Science and Technology (KACST), Riyadh, Kingdom of Saudi Arabia. ${ }^{4}$ Integrated Gulf Biosystems, Riyadh, Kingdom of Saudi Arabia.

Received: 11 July 2017 Accepted: 9 November 2017

Published online: 23 November 2017

\section{References}

1. Chen X, Schluesener HJ. Nanosilver: a nanoproduct in medical application. Toxicol Lett. 2008;176:1-12.

2. Dunn K, Edwards-Jones $\mathrm{V}$. The role of Acticoat with nanocrystalline silver in the management of burns. Burns J. Int. Soc. Burn Inj 2004;30 Suppl 1:S1-9.

3. Franci G, Falanga A, Galdiero S, Palomba L, Rai M, Morelli G, et al. Silver nanoparticles as potential antibacterial agents. Mol. Basel Switz. 2015;20: 8856-74.

4. Lu L, Sun RW-Y, Chen R, Hui C-K, Ho C-M, Luk JM, et al. Silver nanoparticles inhibit hepatitis B virus replication. Antivir Ther. 2008;13:253-62.

5. Microsoft Word - Final_Opinion_Health Effects of Exposure to nanosilver to be published on 1306 2014.docx - scenihr_o_039.pdf [Internet]. [cited 2016 Nov 3]. Available from: http://ec.europa.eu/health/scientific_committees/ emerging/docs/scenihr_o_039.pdf

6. Oyanedel-Craver VA, Smith JA. Sustainable colloidal-silver-impregnated ceramic filter for point-of-use water treatment. Environ Sci Technol. 2008;42:927-33.

7. Prabhu S, Poulose EK. Silver nanoparticles: mechanism of antimicrobial action, synthesis, medical applications, and toxicity effects. Int. Nano Lett. 2012;2:32.

8. Samuel U, Guggenbichler JP. Prevention of catheter-related infections: the potential of a new nano-silver impregnated catheter. Int J Antimicrob Agents. 2004;23(Suppl 1):S75-8

9. Saeb ATM, Alshammari AS, Al-Brahim H, Al-Rubeaan KA. Production of silver nanoparticles with strong and stable antimicrobial activity against highly pathogenic and multidrug resistant bacteria. ScientificWorldJournal. 2014;2014:704708.

10. Velázquez-Velázquez JL, Santos-Flores A, Araujo-Meléndez J, SánchezSánchez R, Velasquillo C, González C, et al. Anti-biofilm and cytotoxicity activity of impregnated dressings with silver nanoparticles. Mater Sci Eng C Mater Biol Appl. 2015;49:604-11.

11. Lullove EJ, Bernstein B. Use of SilvrSTAT ${ }^{\oplus}$ in lower extremity wounds: a two center case series « Journal of Diabetic Foot Complications 2015;7:13-16.

12. Hendry AT, Stewart IO. Silver-resistant Enterobacteriaceae from hospital patients. Can J Microbiol. 1979;25:915-21.

13. McHugh GL, Moellering RC, Hopkins CC, Swartz MN. Salmonella typhimurium resistant to silver nitrate, chloramphenicol, and ampicillin. Lancet Lond Engl. 1975:1:235-40.

14. Gunawan C, Teoh WY, Marquis CP. Amal R. Induced adaptation of Bacillus sp to antimicrobial nanosilver Small Weinh Bergstr Ger. 2013:9:3554-60.

15. Jansen AM, Lockatell CV, Johnson DE, Mobley HLT. Visualization of Proteus Mirabilis morphotypes in the urinary tract: the elongated swarmer cell is rarely observed in ascending urinary tract infection. Infect Immun. 2003;71:3607-13.

16. Mobley HL, Belas R. Swarming and pathogenicity of Proteus Mirabilis in the urinary tract. Trends Microbiol. 1995;3:280-4

17. Mathur S, Sabbuba NA, Suller MTE, Stickler DJ, Feneley RCL. Genotyping of urinary and fecal Proteus Mirabilis isolates from individuals with long-term urinary catheters. Eur. J. Clin. Microbiol. Infect. Dis. Off. Publ. Eur. Soc. Clin. Microbiol. 2005;24:643-4.

18. Nicolle LE. Catheter-related urinary tract infection. Drugs Aging. 2005;22:627-39.

19. Armbruster CE, Mobley HLT. Merging mythology and morphology: the multifaceted lifestyle of Proteus Mirabilis. Nat Rev Microbiol. 2012;10:743-54. 
20. Jacobsen SM, Stickler DJ, Mobley HLT, Shirtliff ME. Complicated catheterassociated urinary tract infections due to Escherichia Coli and Proteus Mirabilis. Clin Microbiol Rev. 2008;21:26-59.

21. Rózalski A, Sidorczyk Z, Kotełko K. Potential virulence factors of Proteus bacilli. Microbiol Mol Biol Rev MMBR. 1997;61:65-89.

22. Bronze MS, Cunha BA. Diabetic Foot Infections: Practice Essentials, Background, Pathophysiology [Internet]. 2016 [cited 2016 Nov 3]. Available from: http://emedicine.medscape.com/article/237378-overview

23. Gonzalez G, Bronze MS. Proteus Infections: Background, Pathophysiology, Epidemiology [Internet]. 2016 [cited 2016 Nov 3]. Available from: http:// emedicine.medscape.com/article/226434-overview

24. Pearson MM, Sebaihia M, Churcher C, Quail MA, Seshasayee AS, Luscombe NM, et al. Complete genome sequence of uropathogenic Proteus Mirabilis, a master of both adherence and motility. J Bacteriol. 2008;190:4027-37.

25. Habibi M, Asadi Karam MR, Bouzari S. In silico design of fusion protein of FimH from uropathogenic Escherichia Coli and MrpH from Proteus Mirabilis against urinary tract infections. Adv. Biomed Res. 2015;4:217.

26. Baldo C, Rocha SPD. Virulence factors of Uropathogenic Proteus Mirabilis - a mini review. Int. J. Technol. Enhanc. Emerg. Eng. Res. 2014;3:24-7.

27. Bush K. Alarming $\beta$-lactamase-mediated resistance in multidrug-resistant Enterobacteriaceae. Curr Opin Microbiol. 2010;13:558-64.

28. Nordmann P, Naas T, Poirel L. Global spread of Carbapenemase-producing Enterobacteriaceae. Emerg Infect Dis. 2011;17:1791-8.

29. Horner CS, Abberley N, Denton M, Wilcox MH. Surveillance of antibiotic susceptibility of Enterobacteriaceae isolated from urine samples collected from community patients in a large metropolitan area, 2010-2012. Epidemiol Infect. 2014;142:399-403.

30. Miró E, Agüero J, Larrosa MN, Fernández A, Conejo MC, Bou G, et al. Prevalence and molecular epidemiology of acquired AmpC $\beta$-lactamases and carbapenemases in Enterobacteriaceae isolates from 35 hospitals in Spain. Eur J Clin Microbiol Infect Dis Off Publ Eur Soc Clin Microbiol. 2013;32:253-9.

31. Sheng W-H, Badal RE, Hsueh P-R, Program SMART. Distribution of extendedspectrum $\beta$-lactamases, AmpC $\beta$-lactamases, and carbapenemases among Enterobacteriaceae isolates causing intra-abdominal infections in the AsiaPacific region: results of the study for monitoring antimicrobial resistance trends (SMART). Antimicrob Agents Chemother. 2013;57:2981-8.

32. Bouchillon SK, Badal RE, Hoban DJ, Hawser SP. Antimicrobial susceptibility of inpatient urinary tract isolates of gram-negative bacilli in the United States: results from the study for monitoring antimicrobial resistance trends (SMART) program: 2009-2011. Clin Ther. 2013;35:872-7.

33. Hawser SP, Badal RE, Bouchillon SK, Hoban DJ, Hackel MA, Biedenbach DJ, et al. Susceptibility of gram-negative aerobic bacilli from intra-abdominal pathogens to antimicrobial agents collected in the United States during 2011. J Inf Secur. 2014;68:71-6.

34. Karlowsky JA, Adam HJ, Baxter MR, Lagacé-Wiens PRS, Walkty AJ, Hoban DJ, et al. Vitro activity of ceftaroline-avibactam against gram-negative and gram-positive pathogens isolated from patients in Canadian hospitals from 2010 to 2012: results from the CANWARD surveillance study. Antimicrob Agents Chemother. 2013;57:5600-11.

35. Sader HS, Farrell DJ, Flamm RK, Jones RN. Antimicrobial susceptibility of gram-negative organisms isolated from patients hospitalized in intensive care units in United States and European hospitals (2009-2011). Diagn Microbiol Infect Dis. 2014;78:443-8.

36. Chen L, Al Laham N, Chavda KD, Mediavilla JR, Jacobs MR, Bonomo RA, et al. First report of an OXA-48-producing multidrug-resistant Proteus Mirabilis strain from Gaza, Palestine. Antimicrob Agents Chemother. 2015;59:4305-7.

37. Latif U, Al-Rubeaan K, Saeb ATM. A review on antimicrobial chitosan-silver nanocomposites: a roadmap toward pathogen targeted synthesis. Int J Polym Mater Polym Biomater. 2015;64:448-58.

38. Matuschek E, Brown DFJ, Kahlmeter G. Development of the EUCAST disk diffusion antimicrobial susceptibility testing method and its implementation in routine microbiology laboratories. Clin. Microbiol. Infect. Off. Publ. Eur. Soc. Clin. Microbiol. Infect Dis. 2014;20:0255-66.

39. Holla G, Yeluri R, Munshi AK. Evaluation of minimum inhibitory and minimum bactericidal concentration of nano-silver base inorganic antimicrobial agent (Novaron( $\left.{ }^{\circledR}\right)$ ) against streptococcus mutans. Contemp. Clin Dent. 2012:3:288-93.

40. Yassien M, Khardori N. Interaction between biofilms formed by Staphylococcus Epidermidis and quinolones. Diagn Microbiol Infect Dis. 2001;40:79-89.

41. Saeb AT, Abouelhoda M, Selvaraju M, Althawadi SI, Mutabagani M, Adil M, et al. The Use of Next-Generation Sequencing in the Identification of a
Fastidious Pathogen: A Lesson From a Clinical Setup. Evol. Bioinforma. Online [Internet]. 2017 [cited 2017 Oct 11];13. Available from: https://www. ncbi.n/m.nih.gov/pmc/articles/PMC5395265/

42. Darling ACE, Mau B, Blattner FR, Perna NT. Mauve: multiple alignment of conserved genomic sequence with rearrangements. Genome Res. 2004;14: 1394-403.

43. Abouelhoda MI, Kurtz S, Ohlebusch E. CoCoNUT: an efficient system for the comparison and analysis of genomes. BMC Bioinformatics. 2008;9:476.

44. Wattam AR, Abraham D, Dalay O, Disz TL, Driscoll T, Gabbard JL, et al. PATRIC, the bacterial bioinformatics database and analysis resource. Nucleic Acids Res. 2014;42:D581-91.

45. Cosentino S, Voldby Larsen M, Møller Aarestrup F, Lund O. PathogenFinderdistinguishing friend from foe using bacterial whole genome sequence data. PLoS One. 2013;8:e77302.

46. VFDB: Virulence Factors Database [Internet]. Virulance Factors Pathog. Bact. 2003 [cited 2016 Nov 3]. Available from: http://www.mgc.ac.cn/NFs/

47. Liu B, Pop M. ARDB-antibiotic resistance genes database. Nucleic Acids Res. 2009;37:D443-7.

48. McArthur AG, Wright GD. Bioinformatics of antimicrobial resistance in the age of molecular epidemiology. Curr Opin Microbiol. 2015;27:45-50.

49. McArthur AG, Waglechner N, Nizam F, Yan A, Azad MA, Baylay AJ, et al. The comprehensive antibiotic resistance database. Antimicrob Agents Chemother. 2013;57:3348-57.

50. Zankari E, Hasman H, Cosentino S, Vestergaard M, Rasmussen S, Lund O, et al. Identification of acquired antimicrobial resistance genes. J Antimicrob Chemother. 2012;67:2640-4.

51. Pal C, Bengtsson-Palme J, Rensing C, Kristiansson E, Larsson DGJ. BacMet: antibacterial biocide and metal resistance genes database. Nucleic Acids Res. 2014:42:D737-43.

52. Olaitan AO, Morand S, Rolain J-M. Mechanisms of polymyxin resistance: acquired and intrinsic resistance in bacteria. Front Microbiol. 2014;5:643.

53. Magiorakos A-P, Srinivasan A, Carey RB, Carmeli Y, Falagas ME, Giske CG, et al. Multidrug-resistant, extensively drug-resistant and pandrug-resistant bacteria: an international expert proposal for interim standard definitions for acquired resistance. Clin. Microbiol. Infect. Off. Publ. Eur. Soc. Clin. Microbiol. Infect. Dis. 2012;18:268-81.

54. Graves JL, Tajkarimi M, Cunningham Q, Campbell A, Nonga H, Harrison SH, et al. Rapid evolution of silver nanoparticle resistance in Escherichia coli. Front. Genet. [Internet]. 2015 [cited 2017 Oct 16];6. Available from: https://www.ncbi.n/m.nih.gov/pmc/articles/PMC4330922/

55. Tang Z, Liu S, Dong S, Wang E. Electrochemical synthesis of ag nanoparticles on functional carbon surfaces. J Electroanal Chem. 502:146-51.

56. Park H-J, Kim JY, Kim J, Lee J-H, Hahn J-S, MB G, et al. Silver-ion-mediated reactive oxygen species generation affecting bactericidal activity. Water Res. 2009;43:1027-32.

57. Beier S, Bertilsson S. Bacterial chitin degradation-mechanisms and ecophysiological strategies. Front Microbiol. 2013;4:149.

58. Vaaje-Kolstad G, Horn SJ, van Aalten DMF, Synstad B, Eijsink VGH. The noncatalytic chitin-binding protein CBP21 from Serratia Marcescens is essential for chitin degradation. J Biol Chem. 2005;280:28492-7.

59. Svitil AL, Chadhain S, Moore JA, Kirchman DL. Chitin degradation proteins produced by the marine bacterium Vibrio Harveyi growing on different forms of chitin. Appl Environ Microbiol. 1997;63:408-13.

60. Wieczorek AS, Hetz SA, Kolb S. Microbial responses to chitin and chitosan in oxic and anoxic agricultural soil slurries. Biogeosciences. 2014;11:3339-52.

61. Gupta V, Prasanna R, Natarajan C, Srivastava AK, Sharma J. Identification, characterization, and regulation of a novel antifungal chitosanase gene (cho) in anabaena spp. Appl Environ Microbiol. 2010;76:2769-77.

62. Gupta V, Prasanna R, Srivastava AK, Sharma J. Purification and characterization of a novel antifungal endo-type chitosanase from anabaena fertilissima. Ann Microbiol. 2011;62:1089-98.

63. Cutting $K$, White $R$, Edmonds $M$. The safety and efficacy of dressings with silver - addressing clinical concerns. Int Wound J. 2007:4:177-84.

64. McInroy L, Cullen B, Clark R. Are silver-containing dressings effective against bacteria in biofilms? [internet]. Orlando; 2010. Available from: www. systagenix.it/cms/uploads/McInroy_biofilms_SAWC_2010.pdf

65. Stephens S, Clark R, Del Bono M, Snyder R. Designing in vitro, in vivo and clinical evaluations to meet the needs of the patient and clinician: dressing wound adherence. Geneva; 2010.

66. Thomas S. Alginate dressings in surgery and wound management-part 1. J Wound Care. 2000;9:56-60. 
67. Thomas S. Alginate dressings in surgery and wound management: part 2. J Wound Care. 2000;9:115-9.

68. Thomas S. Alginate dressings in surgery and wound management: part 3. J Wound Care. 2000;9:163-6.

69. Exsalt ${ }^{\oplus}$ SD7 Powerful and effective interaction with microbes. [Internet]. [cited 2016 Nov 3]. Available from: http://www.excitontech.com/images/ docs/exsalt\%20Science\%20Broad\%20Spectrum.pdf

70. Haycocks S, Chadwick P. Using an activated charcoal dressing with silver for malodour, infection and overgranulation in diabetic foot ulcers importance of appropriate dressing selection for diabetic foot ulcers. Diabet Foot J. 2014;17:74-7.

71. Allison C, Lai HC, Hughes C. Co-ordinate expression of virulence genes during swarm-cell differentiation and population migration of Proteus Mirabilis. Mol Microbiol. 1992;6:1583-91.

72. Butler MT, Wang Q, Harshey RM. Cell density and mobility protect swarming bacteria against antibiotics. Proc Natl Acad Sci U S A. 2010;107:3776-81.

73. Lai S, Tremblay J, Déziel E. Swarming motility: a multicellular behaviour conferring antimicrobial resistance. Environ Microbiol. 2009;11:126-36.

74. Gadagkar R. SURVIVAL STRATEGIES: COOPERATION AND CONFLICT IN ANIMAL SOCIETIES. [Internet]. Cambridge, Massachusetts: Harvard University Press; 1997 [cited 2016 Nov 3]. Available from: https://www.researchgate. net/publication/276238210_Gadagkar_R_1997_SURVIVAL_STRATEGIES_ COOPERATION_AND_CONFLICT_IN_ANIMAL_SOCIETIES_Harvard_ University_Press_Cambridge_Massachusetts_X_196_pp_ISBN_0-674-170555_price_hardcover_2200

75. Hamilton WD. Geometry for the selfish herd. J Theor Biol. 1971:31:295-311.

76. Wu YL, Liu KS, Yin XT, Fei RM. GlpC gene is responsible for biofilm formation and defense against phagocytes and imparts tolerance to $\mathrm{pH}$ and organic solvents in Proteus vulgaris. Genet Mol Res GMR. 2015;14:10619-29.

77. Jiang S-S, Liu M-C, Teng L-J, Wang W-B, Hsueh P-R, Liaw S-J. Proteus Mirabilis pmrl, an RppA-regulated gene necessary for polymyxin $B$ resistance, biofilm formation, and urothelial cell invasion. Antimicrob Agents Chemother. 2010;54:1564-71.

78. Chien C-C, Lin B-C, Biofilm WC-H. Formation and heavy metal resistance by an environmental pseudomonas sp. Biochem Eng J. 2013;78:132-7.

79. Nocelli N, Bogino PC, Banchio E, Giordano W. Roles of extracellular polysaccharides and biofilm formation in heavy metal resistance of rhizobia. Materials. 2016:9:418

80. Høiby N, Bjarnsholt T, Givskov M, Molin S, Ciofu O. Antibiotic resistance of bacterial biofilms. Int J Antimicrob Agents. 2010;35:322-32.

81. Li XZ, Nikaido H, Williams KE. Silver-resistant mutants of Escherichia Coli display active efflux of ag+ and are deficient in porins. J Bacteriol. 1997;179:6127-32.

82. Lok C-N, Ho C-M, Chen R, Tam PK-H, Chiu J-F, Che C-M. Proteomic identification of the Cus system as a major determinant of constitutive Escherichia Coli Silver resistance of chromosomal origin. J Proteome Res. 2008;7:2351-6

83. Randall CP, Gupta A, Jackson N, Busse D, O'Neill AJ. Silver resistance in gram-negative bacteria: a dissection of endogenous and exogenous mechanisms. J Antimicrob Chemother. 2015;70:1037-46.

84. Zhang W, Yin K, Li B, Chen LA. Glutathione S-transferase from Proteus Mirabilis involved in heavy metal resistance and its potential application in removal of $\mathrm{Hg}^{2+}$. J Hazard Mater. 2013;261:646-52.

85. Nair PMG, Choi J. Identification, characterization and expression profiles of Chironomus Riparius glutathione S-transferase (GST) genes in response to cadmium and silver nanoparticles exposure. Aquat Toxicol Amst Neth. 2011; 101:550-60.

86. Toptchieva A, Sisson G, Bryden $\sqcup$, Taylor DE, Hoffman PS. An inducible telluriteresistance operon in Proteus Mirabilis. Microbiol Read Engl. 2003;149:1285-95.

87. Qin J, Lehr CR, Yuan C, Le XC, McDermott TR, Rosen BP. Biotransformation of arsenic by a Yellowstone thermoacidophilic eukaryotic alga. Proc Natl Acad Sci U S A. 2009;106:5213-7.

88. Qin J, Rosen BP, Zhang Y, Wang G, Franke S, Rensing C. Arsenic detoxification and evolution of trimethylarsine gas by a microbial arsenite S-adenosylmethionine methyltransferase. Proc Natl Acad Sci U S A. 2006;103:2075-80.

89. Marchler-Bauer A, Derbyshire MK, Gonzales NR, Lu S, Chitsaz F, Geer LY, et al. CDD: NCBI's conserved domain database. Nucleic Acids Res. 2015;43: D222-6.

90. Srinivasan VB, Vaidyanathan V, Mondal A, Rajamohan G. Role of the two component signal transduction system CpxAR in conferring cefepime and chloramphenicol resistance in Klebsiella Pneumoniae NTUH-K2044. PLoS One. 2012:7:e33777.
91. Nawaz M, Sung K, Kweon O, Khan S, Nawaz S, Steele R. Characterisation of novel mutations involved in quinolone resistance in Escherichia Coli isolated from imported shrimp. Int J Antimicrob Agents. 2015;45:471-6.

92. Kubanov A, Vorobyev D, Chestkov A, Leinsoo A, Shaskolskiy B, Dementieva $E$, et al. Molecular epidemiology of drug-resistant Neisseria gonorrhoeae in Russia (current status, 2015). BMC Infect Dis. 2016;16:389.

93. Jin DJ, Gross CA. Mapping and sequencing of mutations in the Escherichia Coli rpoB gene that lead to rifampicin resistance. J Mol Biol. 1988;202:45-58.

94. Zhao J, Aoki T. Cloning and nucleotide sequence analysis of a chloramphenicol acetyltransferase gene from vibrio anguillarum. Microbiol Immunol. 1992;36:695-705.

95. Bay DC, Rommens KL, Turner RJ. Small multidrug resistance proteins: a multidrug transporter family that continues to grow. Biochim Biophys Acta. 2008;1778:1814-38.

96. Lee J-Y, Ko KS. Mutations and expression of PmrAB and PhoPQ related with colistin resistance in Pseudomonas Aeruginosa clinical isolates. Diagn Microbiol Infect Dis. 2014;78:271-6.

97. Franke S, Grass G, Rensing C, Nies DH. Molecular analysis of the coppertransporting efflux system CusCFBA of Escherichia Coli. J Bacteriol. 2003;185: 3804-12.

98. Nishino K, Nikaido E, Yamaguchi A. Regulation of multidrug efflux systems involved in multidrug and metal resistance of salmonella enterica serovar typhimurium. J Bacteriol. 2007;189:9066-75.

99. Outten FW, Huffman DL, Hale JA, O'Halloran TV. The independent cue and cus systems confer copper tolerance during aerobic and anaerobic growth in Escherichia Coli. J Biol Chem. 2001;276:30670-7.

100. Andersson DI. Persistence of antibiotic resistant bacteria. Curr Opin Microbiol. 2003:6:452-6.

\section{Submit your next manuscript to BioMed Central and we will help you at every step:}

- We accept pre-submission inquiries

- Our selector tool helps you to find the most relevant journal

- We provide round the clock customer support

- Convenient online submission

- Thorough peer review

- Inclusion in PubMed and all major indexing services

- Maximum visibility for your research

Submit your manuscript at www.biomedcentral.com/submit

) BioMed Central 